SRNL-STT-2009-00639

\title{
ASSESSMENT OF THE POTENTIAL FOR HYDROGEN GENERATION DURING GROUTING OPERATIONS IN THE R- AND P-REACTOR VESSELS
}

\author{
B. J. WIERSMA \\ Savannah River National Laboratory \\ Materials Science and Technology Directorate
}

Publication Date: October 2009

This document was prepared in conjunction with work accomplished under Contract No. DEAC09-08SR22470 with the U. S. Department of Energy

\section{We Put Science To Work"}

The Savannah River National Laboratory is managed and operated for the U.S. Department of Energy by

S A VAN NAH RIVER NUCLEAR SOLUTIONS, L LC AIKEN, SC USA $29808 \cdot S R N L$. DOE.GOV 


\section{DISCLAIMER}

This report was prepared under an agreement with and funded by the U. S. Government. Neither the U. S. Government or its employees, nor any of its contractors, subcontractors or their employees, makes any express or implied: 1. warranty or assumes any legal liability for the accuracy, completeness, or for the use of results of such use of any information, product or process disclosed; or 2. representation that such use or results of such use would not infringe privately owned rights; or 3. endorsement or recommendation of any specifically identified commercial product, process or service. Any views and opinions of authors expressed in this work do not necessarily state or reflect those of the United States Government, or its contractors, or subcontractors. 
October, 2009

SRNL-STI-2009-00639

DOCUMENT: SRNS-STI-2009-00639

TITLE: Assessment of the Potential for Hydrogen Generation During Grouting Operations in the R- and P- Reactor Vessels

\section{APPROVALS}

Date:

B. J. Wiersma, Author

Materials Performance and Corrosion Technology

Materials Science and Technology

Date:

B. Garcia-Diaz, Technical Reviewer

Materials Performance and Corrosion Technology

Materials Science and Technology Directorate

K. E. Zeigler, Manager

Materials Performance and Corrosion Technology

Materials Science and Technology Directorate

Date:

J. K. Blankenship, Customer

SDD Decommisioning Engineering 


\section{Table of Contents}

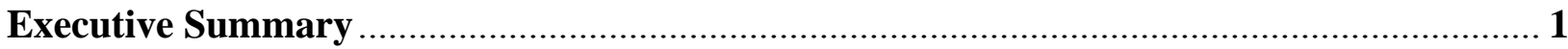

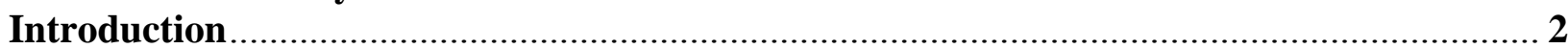

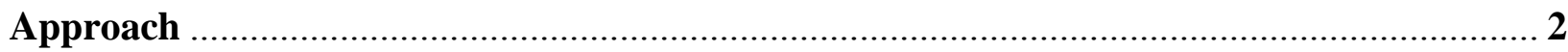

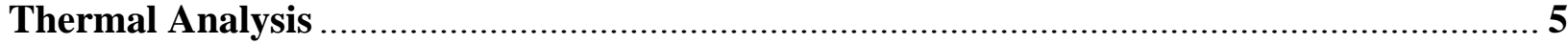

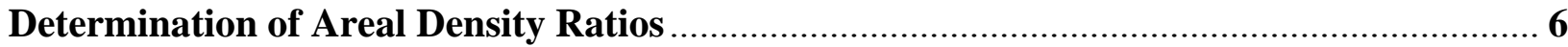

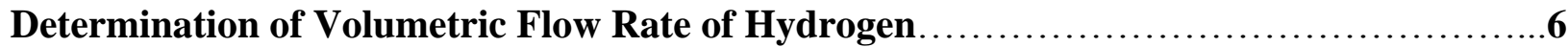

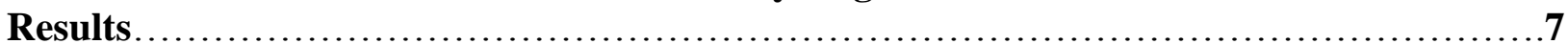

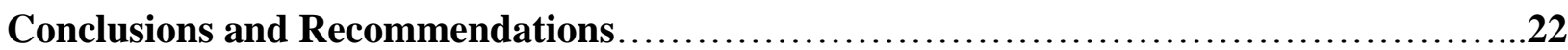

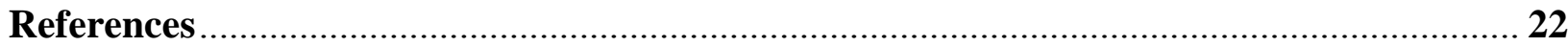

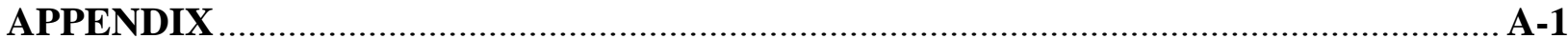




\section{Assessment of the Potential for Hydrogen Generation During Grouting Operations in the $\mathbf{R}$ - and P-Reactor Vessels}

\section{Executive Summary}

The R- and P-reactor buildings were retired from service and are now being prepared for deactivation and decommissioning (D\&D). D\&D activities will consist primarily of immobilizing contaminated components and structures in a grout-like formulation. Aluminum corrodes very rapidly when it comes in contact with the alkaline grout materials and as a result produces hydrogen gas. To address this potential deflagration/explosion hazard, the Materials Science and Technology Directorate (MS\&T) of the Savannah River National Laboratory (SRNL) has been requested to review and evaluate existing experimental and analytical studies of this issue to determine if any process constraints on the chemistry of the fill material and the fill operation are necessary.

Various options exist for the type of grout material that may be used for D\&D of the reactor vessels. The grout formulation options include ceramicrete $(\mathrm{pH} \mathrm{6-8),} \mathrm{low} \mathrm{pH}$ portland cement + silica fume grout $(\mathrm{pH} 10.4)$, or portland cement grout $(\mathrm{pH} \mathrm{12.5)}$. The assessment concluded that either ceramicrete or the silica fume grout may be used to safely grout the R- and P- reactor vessels. The risk of accumulation of a flammable mixture of hydrogen between the grout-air interface and the top of the reactor is very low. Conservative calculations estimate that either ceramicrete or the silica fume grout may be used to safely grout the R-and P- reactor vessels. The risk of accumulation of a flammable mixture of hydrogen between the grout-air interface and the top of the reactor is very low. Although these calculations are conservative, there are some measures that may be taken to further minimize the potential for hydrogen evolution.

1. Minimize the temperature of the grout as much as practical. Lower temperatures will mean lower hydrogen generation rates. Grout temperatures less than $100{ }^{\circ} \mathrm{C}$ should however, still provide an adequate safety margin for the $\mathrm{pH} 8$ and $\mathrm{pH} 10.4$ grout formulations.

2. Minimize the fill rate as much as practical. Lowering the fill rate takes advantage of passivation of the aluminum components and hence lower hydrogen generation rates. Fill rates that are less than 2 inches/min will reduce the chance of significant hydrogen build-up.

3. Ventilate the building as much as practical (e.g., leave doors open) to further disperse hydrogen. The volumetric hydrogen generation rates however, are low for the $\mathrm{pH} 8$ and $\mathrm{pH} 10.4$ grout, i.e., less than $0.32 \mathrm{ft}^{3} / \mathrm{min}$.

Portland cement grout, on the other hand, for the same range of process parameters does not provide a significant margin of safety against the accumulation of flammable gas in the reactor vessel during grouting operations. It is recommended that this grout not be 
utilized for this task. If further walk-down inspections of the reactor vessels suggest an increase in the actual areal density of aluminum, the calculations should be re-visited.

\section{Introduction}

The R- and P-reactor buildings were retired from service and are now being prepared for deactivation and decommissioning. D\&D activities will consist primarily of immobilizing contaminated components and structures in a grout-like formulation. This report specifically addresses the grouting of the reactor vessels along with the aluminum components that are contained with the vessel [1].

The aluminum components contained in the reactor pose a concern in that aluminum will corrode very rapidly when it comes in contact with the very alkaline grout materials, and as a result produce hydrogen gas. To address this potential deflagration/explosion hazard, the Materials Science and Technology Directorate (MS\&T) of the Savannah River National Laboratory (SRNL) has been requested to review and evaluate existing experimental and analytical studies of this issue to determine if any process constraints on the chemistry of the fill material and the fill operation are necessary.

Various options exist for the type of grout material that may be used for D\&D of the reactor vessels. The grout formulation options include ceramicrete $(\mathrm{pH} \mathrm{6-8),} \mathrm{low} \mathrm{pH}$

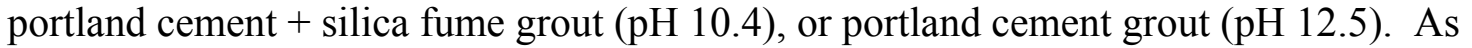
part of this task, the rate of hydrogen generation in the vessels for grouts with a $\mathrm{pH}$ range from 8 to 13 will be calculated. The calculations considered such factors as temperature, the rate at which the grout fills the vessel, the surface area of the components present, the surface area of the reactor vessel and the void volume of the reactor vessel. The principles utilized in calculating the hydrogen generation rate from the R-and P-reactor disassembly basins were employed [2]. The objective of these calculations was to provide input as to which grout formulation is appropriate for the operations so that the risk of hydrogen gas accumulation is minimized.

\section{Approach}

Pacific Northwest National Laboratory (PNNL) performed a similar analysis for the K basins at the Hanford Site [3]. This analysis was reviewed and applied to the situation for the $\mathrm{R}$ - and $\mathrm{P}$ - reactor vessels. The process is as follows:

1) Aluminum corrodes upon exposure to the grout.

2) Hydrogen is generated as a consequence of the corrosion reaction.

3) The gas rises to the surface of the grout in the form of bubbles.

4) The bubbles will burst at the grout surface releasing $\mathrm{H}_{2}$ gas into the stagnant air layer.

This process was modeled by formulating a kinetic law for hydrogen production as a function of CLSM temperature, $\mathrm{pH}$, fill rate and combining it with a model for vertical turbulent diffusion of a light fluid $\left(\mathrm{H}_{2}\right)$ through a heavier miscible fluid medium (air). 
Vertical turbulent diffusion is a process analogous to molecular diffusion. However, the diffusion coefficient is several orders of magnitude larger than the molecular diffusion coefficient for the $\mathrm{H}_{2}$ /air mixture, because vertical diffusion of the lighter gas is due to buoyancy rather than molecular motion. This model has been confirmed experimentally and has been shown to be effective for predicting diffusion layers that are broader than they are tall [4].

The assumptions used in the analysis were:

- There are openings in the reactor vessel that allow hydrogen to escape the vessel.

- Once the hydrogen reaches the top of the reactor vessel, there is sufficient advection to disperse the hydrogen within the building superstructure.

Based on these assumptions the only place that hydrogen could potentially accumulate is in the region between the grout layer and the top of the reactor vessel.

The first part of the model involved developing a kinetic expression for the generation of hydrogen during the corrosion of aluminum. This kinetic expression can be represented by the following relationship:

$\mathrm{Q}=\mathrm{f}(\mathrm{pH}, \mathrm{T}, \mathrm{h})$

Where $\mathrm{Q}$ is the hydrogen generation rate in $\mathrm{cm}^{3} / \mathrm{cm}^{2} / \mathrm{min}$, $\mathrm{T}$ is the grout temperature in ${ }^{\circ} \mathrm{K}$, and $\mathrm{h}$ is the level of the grout as a function of time $\mathrm{t}$ in inches. The derivation of this relationship is shown in the Appendix. The final explicit relationship was:

$\mathrm{Q}=\underline{\mathrm{Q}_{\mathrm{o}}} \underline{* \mathrm{~m} *[1-\exp (-0.0385 * \mathrm{H} / \mathrm{m})]}$

where,

$\mathrm{Q}_{\mathrm{o}}=3 * 10^{-14} * \exp (2.0952 * \mathrm{pH}) * \exp [-5339 *(1 / \mathrm{T}-1 / 303)]$

Where Qo is the hydrogen generation rate as a function of $\mathrm{pH}$ and temperature, $\mathrm{m}$ is the rate at which the grout fill level increases with time, and $\mathrm{H}$ is the fill level at a given time, t.

Laboratory tests performed at PNNL to measure the hydrogen generation rate of noncorroded aluminum metal coupon immersed in both grout and in saturated $\mathrm{Ca}(\mathrm{OH})_{2}$ solution provided part of the technical basis for the parameters that go into the equation. The key results from the tests were:

- The initial hydrogen generation rate of non-corroded aluminum metal in a grout mixture at $25^{\circ} \mathrm{C}$ is $0.3 \mathrm{~cm}^{3} / \mathrm{min}$.

- The hydrogen generation rate of non-corroded aluminum metal in grout decreases to approximately $0.15 \mathrm{~cm}^{3} / \mathrm{min}$ after 2 to 3 hours of exposure to the grout mixture 
at $25^{\circ} \mathrm{C}$. The decrease in corrosion rate is due to the formation of a corrosion product (principally tricalcium aluminum hydroxide and hydrocalumite) layer on the surface of the aluminum metal.

- The hydrogen generation rate for aluminum metal in grout was performed at 27 ${ }^{\circ} \mathrm{C}$. Extrapolation of this result to hydrogen generation rates for higher grout temperatures was made using the test results from aluminum exposed to $\mathrm{Ca}(\mathrm{OH})_{2}$ solution (i.e., similar to the pore solution in the grout). However, the five-fold increase in hydrogen generation rate with a $30{ }^{\circ} \mathrm{C}$ increase in the $\mathrm{Ca}(\mathrm{OH})_{2}$ solution temperature is consistent with literature values for hydrogen generation in grout. Matsuo et al. observed a 3 fold increase in hydrogen generation rate with a $30{ }^{\circ} \mathrm{C}$ increase in an inhibited grout mixture [5].

- Literature data was also used to obtain the corrosion rate as a function of $\mathrm{pH}$. The corrosion rate was then converted to a hydrogen generation rate assuming that 1.5 moles of hydrogen are generated for every one mole of aluminum that corrodes.

The following conservatisms and uncertainties were considered when applying the data to the R- and P- reactor vessel situation.

- The experimentally measured hydrogen generation rate was determined on clean or non-corroded aluminum metal. The surface of the aluminum metal in the reactor vessels is corroded. The aluminum metal in the reactors has been there for many years and the surface is protected by an oxide film. In either case, the rate of hydrogen generation from corrosion would be lower than that measured for the non-corroded aluminum metal coupons in the laboratory tests.

- The hydrogen generation rate due to aluminum metal corroding in grout is based on only one relevant gas generation test. However, four tests were conducted in a $\mathrm{Ca}(\mathrm{OH})_{2}$ solution and the results were consistent based on chemical engineering fundamentals (i.e., mass transfer conditions in the grout are poorer than those in the $\mathrm{Ca}(\mathrm{OH})_{2}$ solution). Additionally, the hydrogen gas generation rate for the aluminum in grout was also comparable to other values in the literature. Matsuo et al. measured a rate of $0.105 \mathrm{~cm}^{3} /$ min for aluminum exposed to Portland cement at room temperature $[6,7]$.

While the last two bullets do indicate that there is uncertainty in the experimental data due to the few number of laboratory tests, it is unlikely that this is significant relative to other conservatisms in the analysis.

The second part of the model involves the mass transport of the hydrogen gas from the surface of the grout to the top of the reactor. The derivation of the mass transport equation is also shown in the Appendix. The following conservatisms and uncertainties were considered when applying the model to the R-and P-reactor vessels.

1) The analysis does not account for dissipation of hydrogen between the surface of the water and the top of the reactor due to advection. Accounting for this phenomenon would minimize the accumulation of hydrogen in this region. 
2) The analysis assumed that the hydrogen bubble plume does not expand laterally from the aluminum metal source. In reality, local concentrated sources of aluminum metal will produce a bubble plume which expands laterally as it rises through the grout. Thus, the potential for a local deflagration/explosion is overestimated in this analysis.

The flux of hydrogen away from the surface is related to the superficial velocity, $\mathrm{u}_{\mathrm{o}}$. The superficial velocity may be expressed as:

$\mathrm{u}_{\mathrm{o}}=\beta^{2} *\left[\mathrm{~g} * \mathrm{H}_{\mathrm{o}} *\left(1-\left(\mathrm{M}_{\mathrm{H} 2} / \mathrm{M}_{\mathrm{air}}\right)\right)^{*} \mathrm{X}_{\mathrm{LFL}}^{3}\right]^{1 / 2}$

where $\beta$ is a proportionality constant, $g$ is the acceleration of gravity, $\mathrm{H}_{\mathrm{o}}$ is the distance between the grout-air interface and the top of the reactor, $M$ is the molecular weight of either hydrogen or air, and $\mathrm{X}$ is the volume $\%$ of hydrogen in air at the lower flammability limit (LFL). In the case of hydrogen the LFL is $4 \%$ by volume.

The incipient flammability condition occurs when the gas generation rate due to corrosion equals the flux of hydrogen through air. The boundary condition at the interface between the grout and air is that the hydrogen gas concentration is at the LFL. For safety class operations, with radioactive materials stored within a vessel, a criterion of $60 \%$ LFL is utilized for the evaluation [8]. The equation that describes this condition is:

$\mathrm{Q} * \mathrm{~A}_{\mathrm{Al}}=\mathrm{u}_{\mathrm{o}} * \mathrm{~A}_{\mathrm{a}}$

where $A_{A l}$ is the surface area of aluminum in contact with grout and $A_{a}$ is the void crosssectional area of the reactor vessel. Equation 5 can be re-arranged to give the critical areal density ratio.

$$
\left[\mathrm{A}_{\mathrm{Al}} / \mathrm{A}_{\mathrm{a}}\right]_{\mathrm{c}}=\mathrm{u}_{\mathrm{o}} / \mathrm{Q}
$$

For the analysis, a plot of $\left[\mathrm{A}_{\mathrm{Al}} / \mathrm{A}_{\mathrm{a}}\right]_{\mathrm{c}} \mathrm{vs}$. $\mathrm{H}$ is prepared. Examples of this plot are shown in Figures 1 through 13. If the critical area density is greater than the actual areal density, there is a low probability of a flammable condition. On the other hand if it is less than the actual areal density, there is a possibility of a flammable condition developing.

\section{Thermal Analysis}

Calorimetry experiments are being conducted to estimate the temperature rise that will occur in the grout during these operations [9]. Maximum temperatures observed during these tests for the different grout formulations may be used for final calculations. For this assessment, case studies will be performed for grout temperatures between 50 and $100{ }^{\circ} \mathrm{C}$ to understand the effect of temperature on the hydrogen generation rate for the various grout formulations. 


\section{Determination of Areal Density Ratios}

Actual areal density ratios are being calculated based on drawings of the vessel and components within the vessel as well as walk-downs of the R-and P-reactor facilities [10]. Enough information has been gathered to make an estimate of the areal density for the P-reactor vessel, however, the final assessment of the R-reactor vessel is not complete as of the writing of this document. Although it is known that the R-reactor vessel contains fewer aluminum components than the P-reactor vessel and thus the areal density is expected to be lower for R-reactor vessel.

The predominant aluminum components present in the reactor vessels are the universal sleeve housing (USH) and thimble tubes. It will be assumed that the inner and outer surfaces of these components will be exposed to the grout. The aluminum surface area, $\mathrm{A}_{\mathrm{Al}}$, as a function of the fill level, $\mathrm{H}$, was calculated from the following relationship:

$$
\mathrm{A}_{\mathrm{Al}}(\mathrm{h})=\mathrm{N}_{\mathrm{USH}} * \pi *\left(\mathrm{D}_{\mathrm{USH}_{-} \mathrm{o}}+\mathrm{D}_{\mathrm{USH}_{-} \mathrm{i}}\right) * \mathrm{H}+\mathrm{N}_{\mathrm{T}} * \pi *\left(\mathrm{D}_{\mathrm{T}_{-} \mathrm{o}}+\mathrm{D}_{\mathrm{T}_{-} \mathrm{i}}\right) * \mathrm{H}
$$

where $\mathrm{D}$ is the diameter of the USH or thimble (T) tubes, o represents the exterior surface, $\mathrm{i}$ represents the interior surface, and $\mathrm{N}$ is the quantity of USH or thimble tubes. The calculation did not include the surface area of the ends of the tubes.

The cross-sectional area of the vessel, $\mathrm{A}_{\mathrm{a}}$, was calculated by subtracting the crosssectional area of the USHs, thimble tubes, septifoils and spargers from the total tank cross-sectional area. This is represented by the following equation:

$\mathrm{A}_{\mathrm{a}}=\pi * \mathrm{D}_{\mathrm{t}}{ }^{2} / 4-\mathrm{N}_{\mathrm{USH}} * \pi *\left(\mathrm{D}_{\mathrm{USH}_{-} \mathrm{o}}{ }^{2}-\mathrm{D}_{\mathrm{USH}_{-} \mathrm{i}}{ }^{2}\right) / 4-\mathrm{N}_{\mathrm{T}} * \pi *\left(\mathrm{D}_{\mathrm{T}_{-} \mathrm{o}}{ }^{2}-\mathrm{D}_{\mathrm{T}_{-} \mathrm{i}}{ }^{2}\right) / 4-\mathrm{N}_{\mathrm{Ss}} * \pi * \mathrm{D}_{\mathrm{SS}}{ }^{2} / 4$

where $\mathrm{a}$ is for the cross-sectional area, $\mathrm{t}$ is for the tank, and ss is for the septifoils and the spargers. In P-reactor it is estimated that there are 432 USH tubes, 61 septifoils, and 66 thimble tubes and 6 spargers [11]. The USH tubes have outer and inner diameters, 4.25 inches and 4.00 inches, respectively. The outer and inner diameters for the thimble tubes are 1.5 inches and 1.0 inches, respectively. The septifoils and spargers were modeled as a cylinder with a diameter of 3.5 inches. Calculations of these areas are exhibited in the Appendix.

\section{Determination of Volumetric Flow Rate of Hydrogen}

The maximum volumetric flow rate of hydrogen generated during the grouting operations was also estimated. Knowledge of this value will assist in the evaluation of whether or not there is adequate ventilation to effectively disperse the hydrogen. The volumetric flow rate, $\mathrm{Q}_{\text {Tот }}$ is calculated from the following equation:

$\mathrm{Q}_{\mathrm{TOT}}=\mathrm{Q} * \mathrm{~A}_{\mathrm{Al}}$

A calculation of this flow rate is exhibited in the Appendix. 


\section{Results}

The case studies that were performed are summarized in Table 1 and the results are shown in Figures 1 through 13. Some of the key trends were:

- An increase in temperature resulted in a lower critical areal density and therefore greater risk of developing a flammable condition (e.g., compare Figures 1 and 2).

- An increase in $\mathrm{pH}$ resulted in a lower critical areal density and therefore a greater risk of developing a flammable condition (e.g., examine any figure).

- An increase in the fill rate resulted in a lower critical areal density, although the effect was not as great as temperature or $\mathrm{pH}$ (see Figure 11).

- The $60 \%$ LFL criterion provides a significant margin on the risk of developing a flammable condition (e.g., compare figures 2 and 13).

- Although it is not shown, if the actual areal density ratio is greater than that assumed in the analysis, there is a greater risk of developing a flammable condition. On the other hand if it is less than that assumed in the analysis (e.g., Rreactor vessel), there is less of a risk of developing a flammable condition.

The most significant result from these case studies is that it demonstrates that two of the grout formulations, the ceramicrete and the silica fume, should not result in a flammable condition during reactor vessel grouting operations as long as they are within the parameters of the case studies. Even at $60 \%$ LFL the critical areal density ratio for the silica fume grout is at least 1 to 2 orders of magnitude greater than actual areal density ratio, while the ratio for the ceramicrete is 3 to 4 orders of magnitude greater. At $100 \%$ LFL these margins increase further to 2 to 3 orders of magnitude for the silica fume grout and 4 to 5 orders of magnitude for the ceramicrete. The Portland cement grout appears to be a viable option at low temperatures and low fill rates. However, there is less margin on the flammable condition and temperatures as low as $70^{\circ} \mathrm{C}$ may result in not meeting the $60 \%$ LFL criterion.

Although these results are encouraging, due to the nature of the accident scenario, taking precautions that minimize the potential for a flammable condition are recommended. These measures include ensuring that the building has adequate ventilation during the grouting process, minimizing the grout temperature, and operating at a slower fill rate. In order to evaluate what would be adequate ventilation, the volumetric flow rate of hydrogen was calculated for each case. The results are summarized in Table 2.

The hydrogen flow rates for the $\mathrm{pH} 8$ and $\mathrm{pH} 10.4$ grout are very small, less than 0.32 $\mathrm{ft}^{3} / \mathrm{min}$. The flow rates for the $\mathrm{pH} 12.5$ grout are higher than those for the lower $\mathrm{pH}$ grouts, ranging from 0.7 to $26 \mathrm{ft}^{3} / \mathrm{min}$, however, the rates appear to be manageable with proper ventilation. 
Table 1. Summary of Case Studies

\begin{tabular}{|c|c|c|c|c|}
\hline Case & $\begin{array}{c}\text { Temperature } \\
\left({ }^{\circ} \mathrm{C}\right)\end{array}$ & $\begin{array}{c}\text { Fill Rate } \\
\text { (inches/minute) }\end{array}$ & $\mathrm{pH}$ & $\begin{array}{c}\text { LFL Level } \\
(\%)\end{array}$ \\
\hline 1 & 50 & 1 & $8,10.4$, and 12.5 & 60 \\
\hline 2 & 100 & 1 & $8,10.4$, and 12.5 & 60 \\
\hline 3 & 70 & 1 & $8,10.4$, and 12.5 & 60 \\
\hline 4 & 80 & 1 & $8,10.4$, and 12.5 & 60 \\
\hline 5 & 50 & 0.5 & $8,10.4$, and 12.5 & 60 \\
\hline 6 & 60 & 0.5 & $8,10.4$, and 12.5 & 60 \\
\hline 7 & 70 & 0.5 & $8,10.4$, and 12.5 & 60 \\
\hline 8 & 50 & 2 & $8,10.4$, and 12.5 & 60 \\
\hline 9 & 60 & 2 & $8,10.4$, and 12.5 & 60 \\
\hline 10 & 70 & 2 & $8,10.4$, and 12.5 & 60 \\
\hline 11 & 70 & 2,8, and 16 & 10.4 & 60 \\
\hline 12 & 100 & 2 & $8,10.4$, and 12.5 & 60 \\
\hline 13 & 100 & 1 & $8,10.4$, and 12.5 & 100 \\
\hline
\end{tabular}

Table 2. Summary of Volumetric Flow Rates of Hydrogen for the Case Studies.

\begin{tabular}{|c|c|c|c|c|c|}
\hline & & & $\mathrm{pH} 10.4$ & $\mathrm{pH} 8$ & pH 12.5 \\
\hline Case & Temperature $\left({ }^{\circ} \mathrm{C}\right)$ & $\begin{array}{c}\text { Fill Rate } \\
\text { (inches } / \mathrm{min} \text { ) }\end{array}$ & $\begin{array}{c}\text { Qtot } \\
\text { (cu.ft./min) }\end{array}$ & $\begin{array}{c}\text { Qtot } \\
\text { (cu.ft./min) }\end{array}$ & $\begin{array}{c}\text { Qtot } \\
\text { (cu.ft./min) }\end{array}$ \\
\hline 1 & 50 & 1 & $1.80 \mathrm{E}-02$ & $1.20 \mathrm{E}-04$ & $1.50 \mathrm{E}+00$ \\
\hline 2 & 100 & 1 & $1.60 \mathrm{E}-01$ & 1.10E-03 & $1.34 \mathrm{E}+01$ \\
\hline 3 & 70 & 1 & $4.70 \mathrm{E}-02$ & $3.10 \mathrm{E}-04$ & $3.80 \mathrm{E}+00$ \\
\hline 4 & 80 & 1 & $7.30 \mathrm{E}-02$ & $4.80 \mathrm{E}-04$ & $6.00 \mathrm{E}+00$ \\
\hline 5 & 50 & 0.5 & 9.00E-03 & 5.90E-05 & 7.00E-01 \\
\hline 6 & 60 & 0.5 & 1.50E-02 & 9.70E-05 & $1.20 \mathrm{E}+00$ \\
\hline 7 & 70 & 0.5 & $2.40 \mathrm{E}-02$ & $1.50 \mathrm{E}-04$ & $1.90 \mathrm{E}+00$ \\
\hline 8 & 50 & 2 & $3.50 \mathrm{E}-02$ & $2.20 \mathrm{E}-04$ & $2.80 \mathrm{E}+00$ \\
\hline 9 & 60 & 2 & $5.70 \mathrm{E}-02$ & $3.80 \mathrm{E}-04$ & $4.70 \mathrm{E}+00$ \\
\hline 10 & 70 & 2 & 9.20E-02 & $6.10 \mathrm{E}-04$ & $7.50 \mathrm{E}+00$ \\
\hline 11 & 70 & 2 & $9.20 \mathrm{E}-02$ & NA & NA \\
\hline 11 & 70 & 8 & $2.20 \mathrm{E}-01$ & NA & NA \\
\hline 11 & 70 & 16 & $2.70 \mathrm{E}-01$ & NA & NA \\
\hline 12 & 100 & 2 & 3.20E-01 & $2.10 \mathrm{E}-03$ & $2.61 \mathrm{E}+01$ \\
\hline 13 & 100 & 1 & $1.60 \mathrm{E}-01$ & $1.10 \mathrm{E}-03$ & $1.34 \mathrm{E}+01$ \\
\hline
\end{tabular}




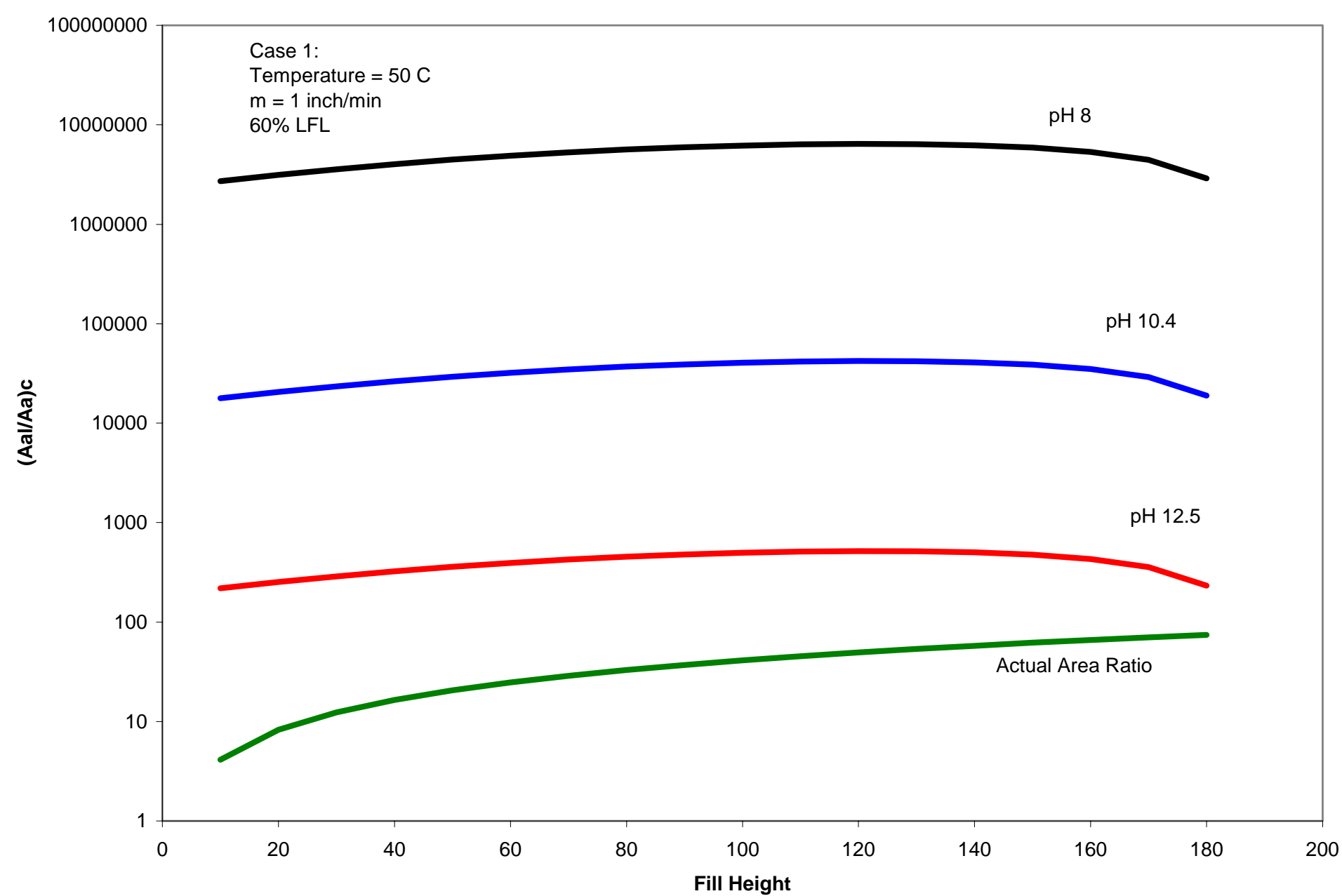

Figure 1. Critical areal density ratio for flammable condition in R\& P Reactor Vessels for Case 1. 


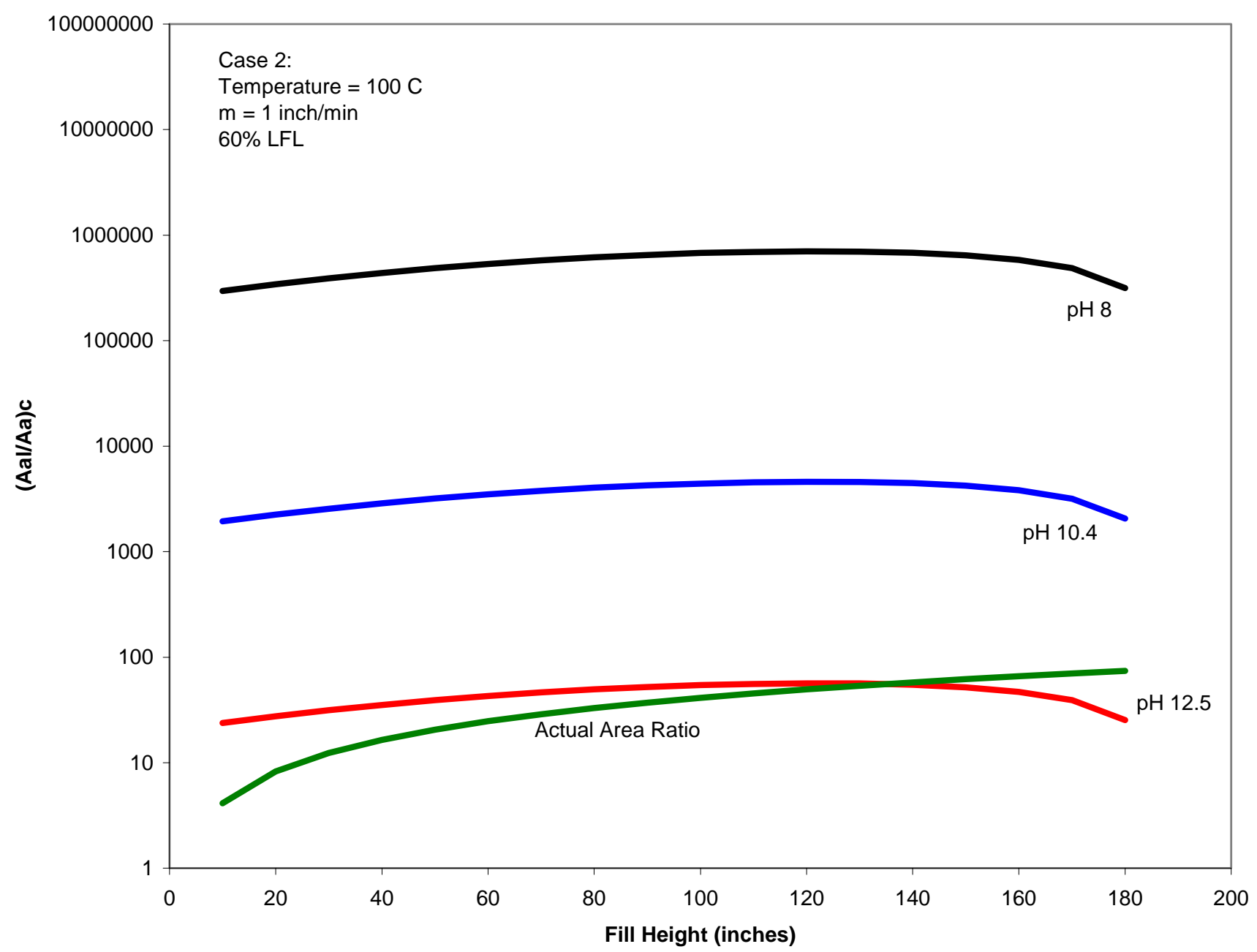

Figure 2. Critical areal density ratio for flammable condition in R\& P Reactor Vessels for Case 2. 


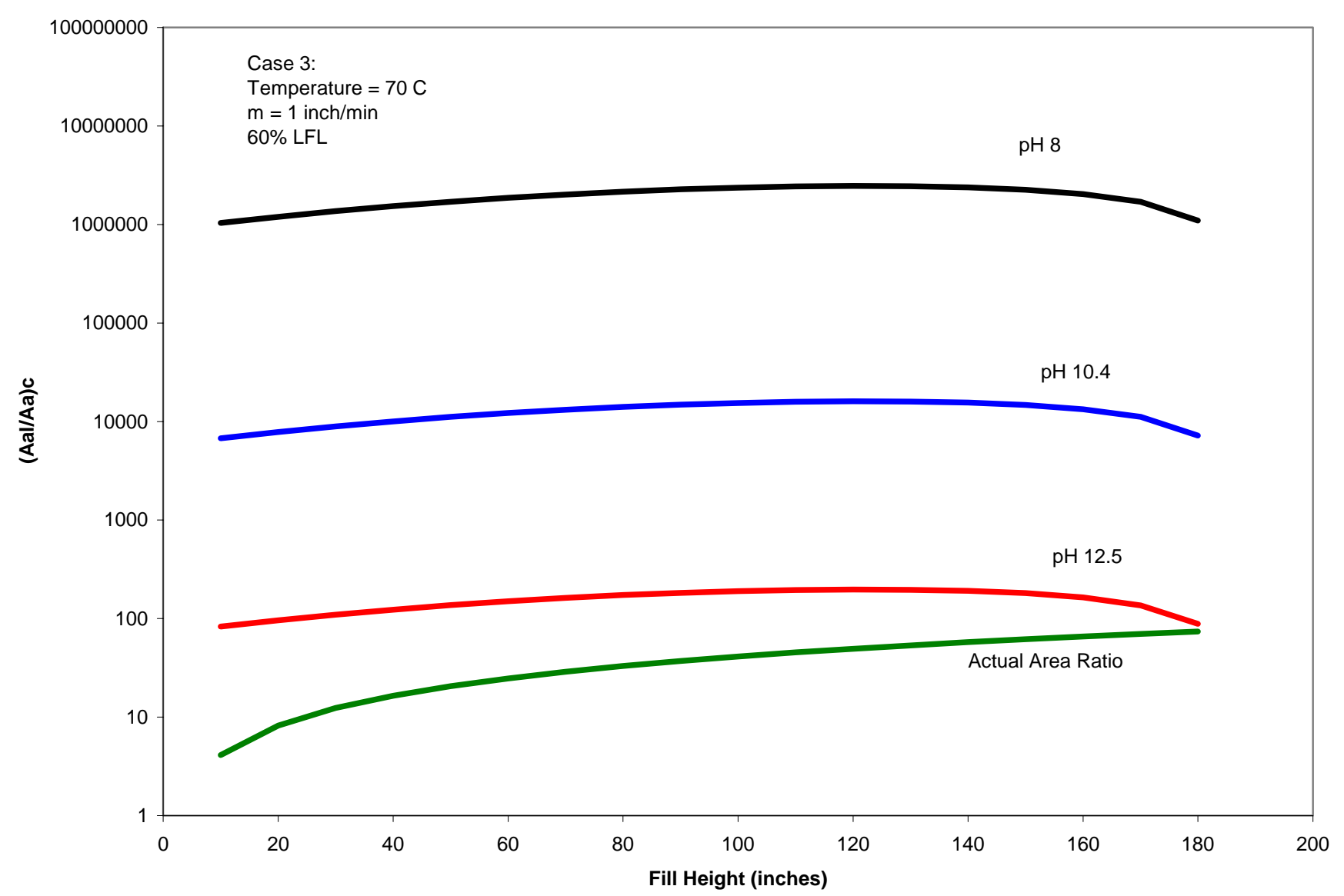

Figure 3. Critical areal density ratio for flammable condition in R\& P Reactor Vessels for Case 3. 


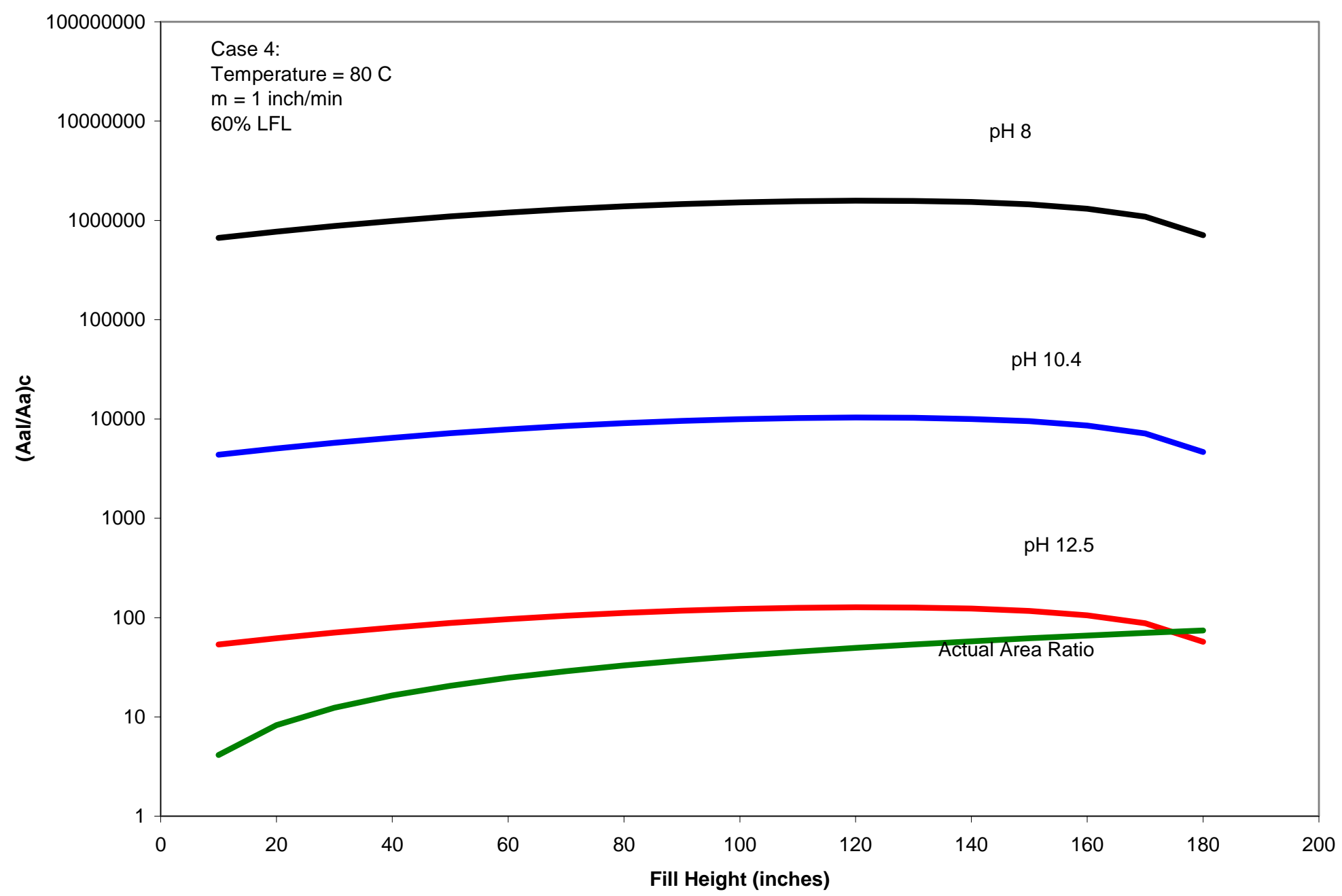

Figure 4. Critical areal density ratio for flammable condition in R\& $P$ Reactor Vessels for Case 4. 


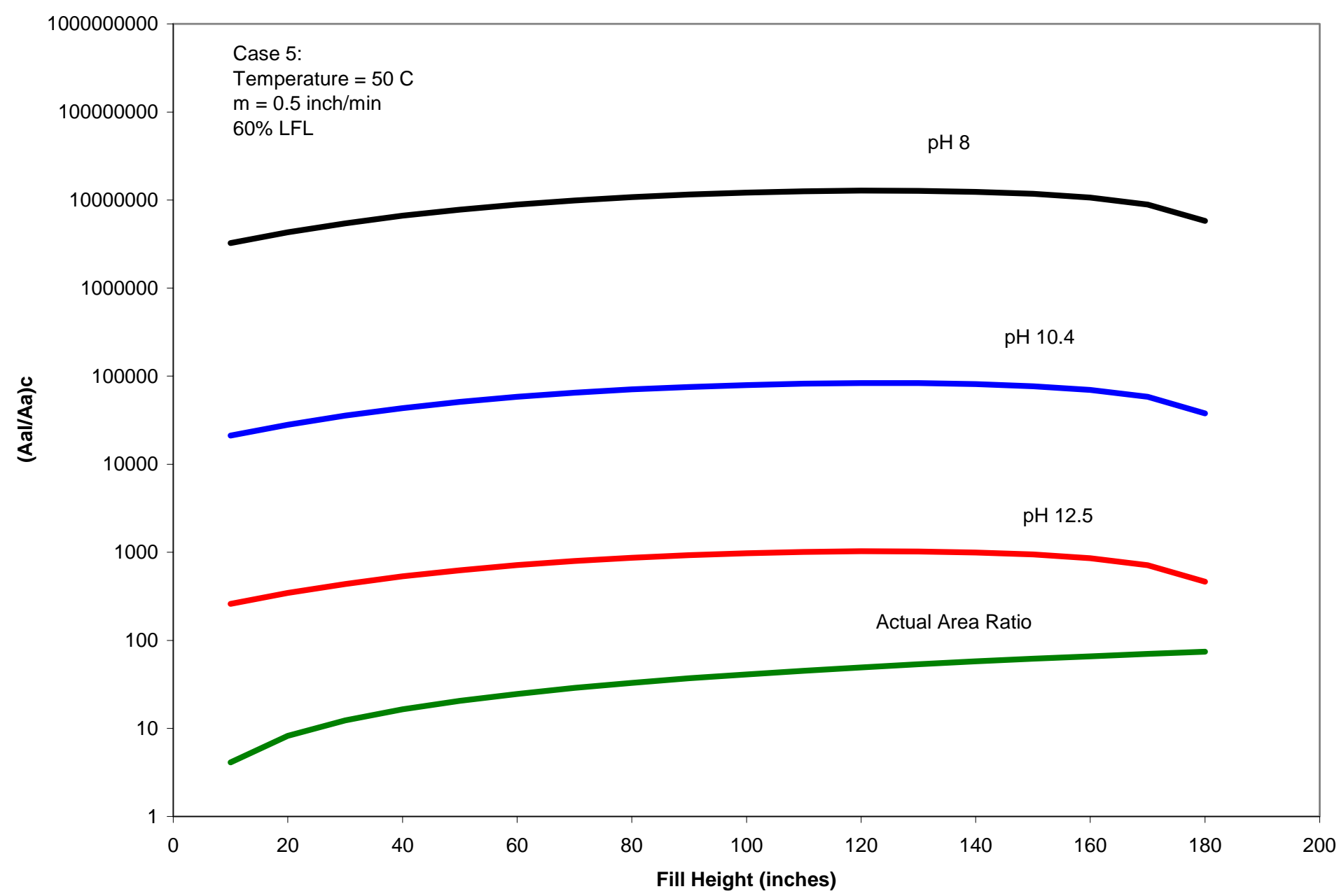

Figure 5. Critical areal density ratio for flammable condition in R\& P Reactor Vessels for Case 5. 


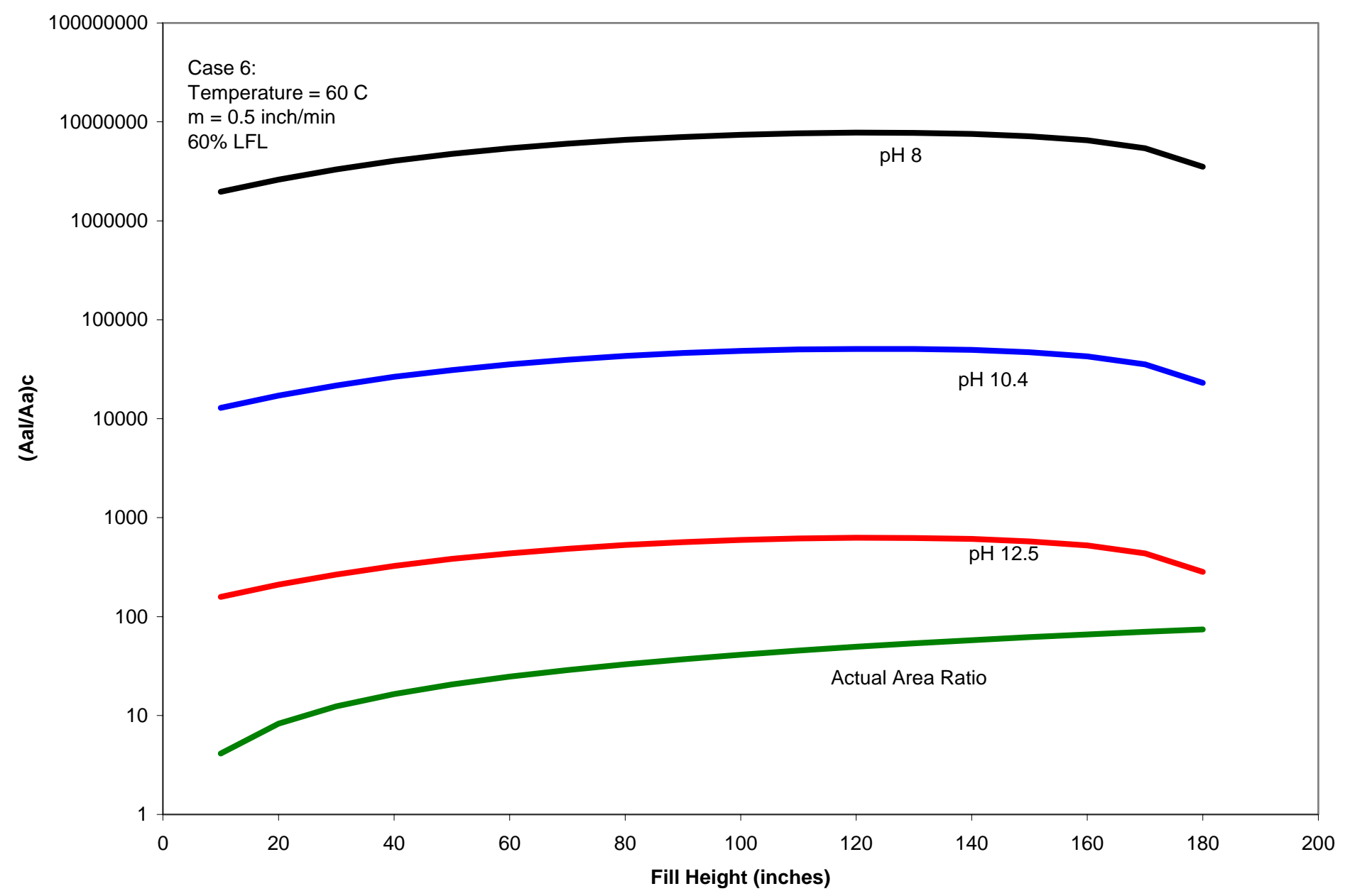

Figure 6. Critical areal density ratio for flammable condition in R\& P Reactor Vessels for Case 6. 


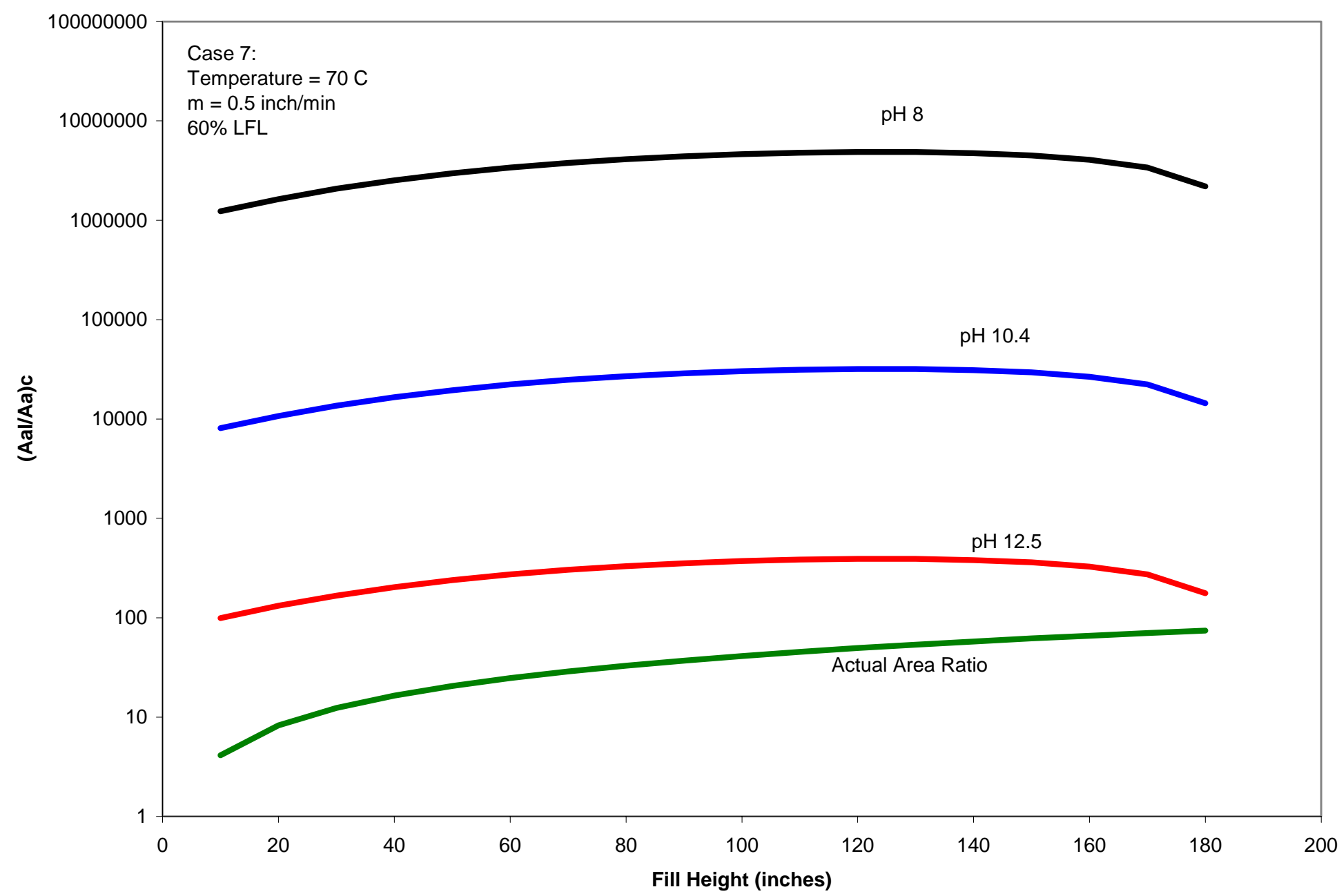

Figure 7. Critical areal density ratio for flammable condition in R\& P Reactor Vessels for Case 7. 


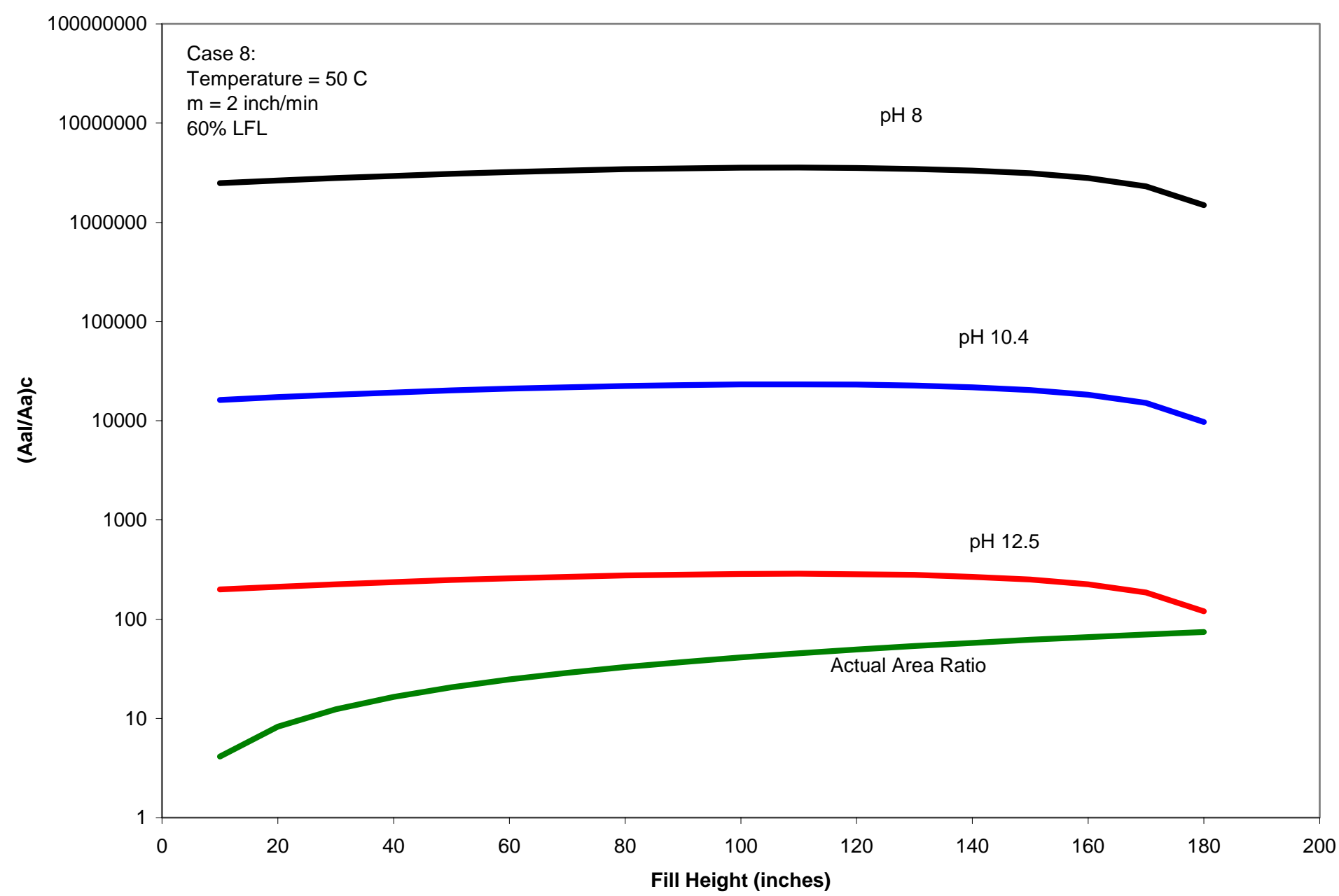

Figure 8. Critical areal density ratio for flammable condition in R\& P Reactor Vessels for Case 8. 


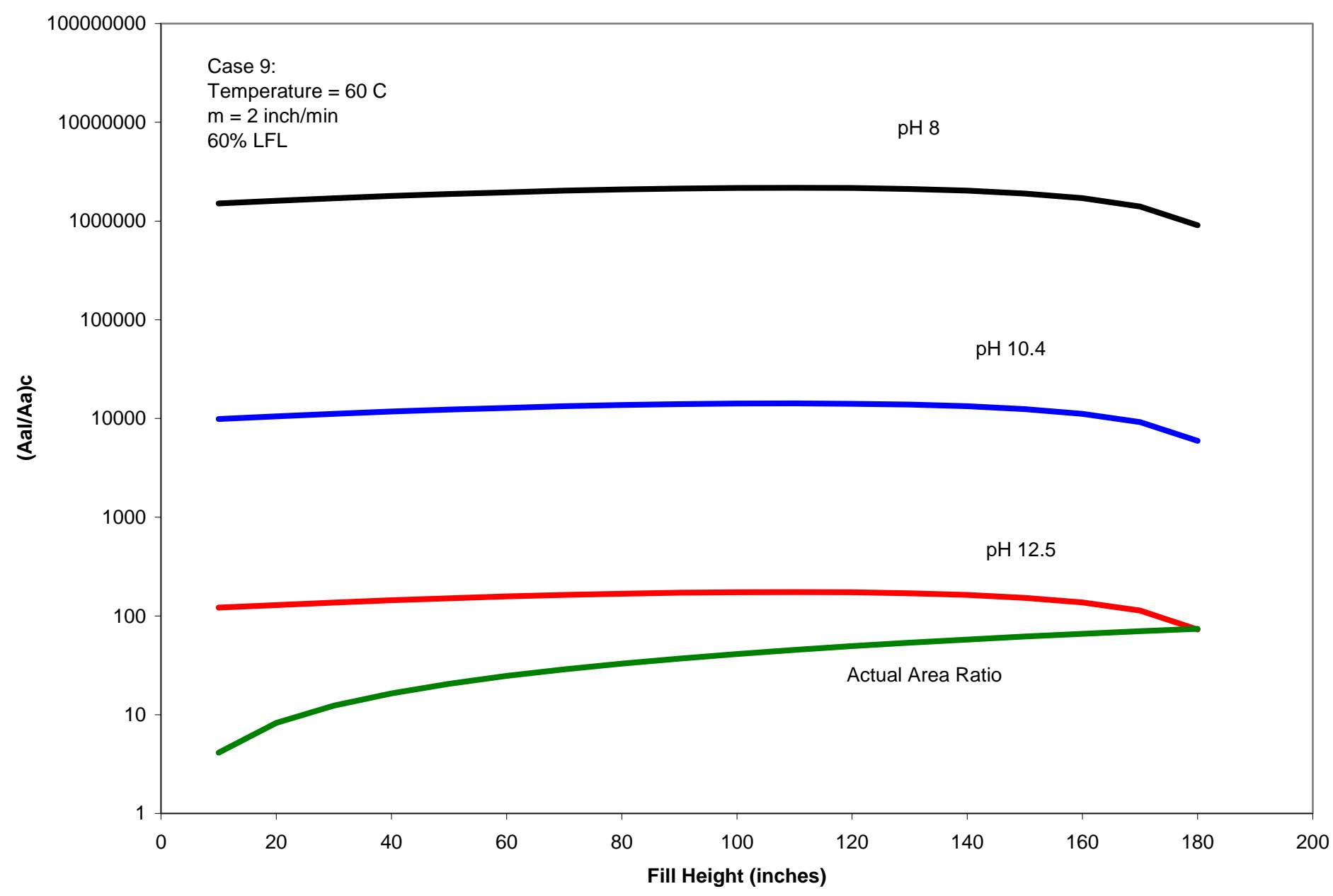

Figure 9. Critical areal density ratio for flammable condition in R\& P Reactor Vessels for Case 9. 


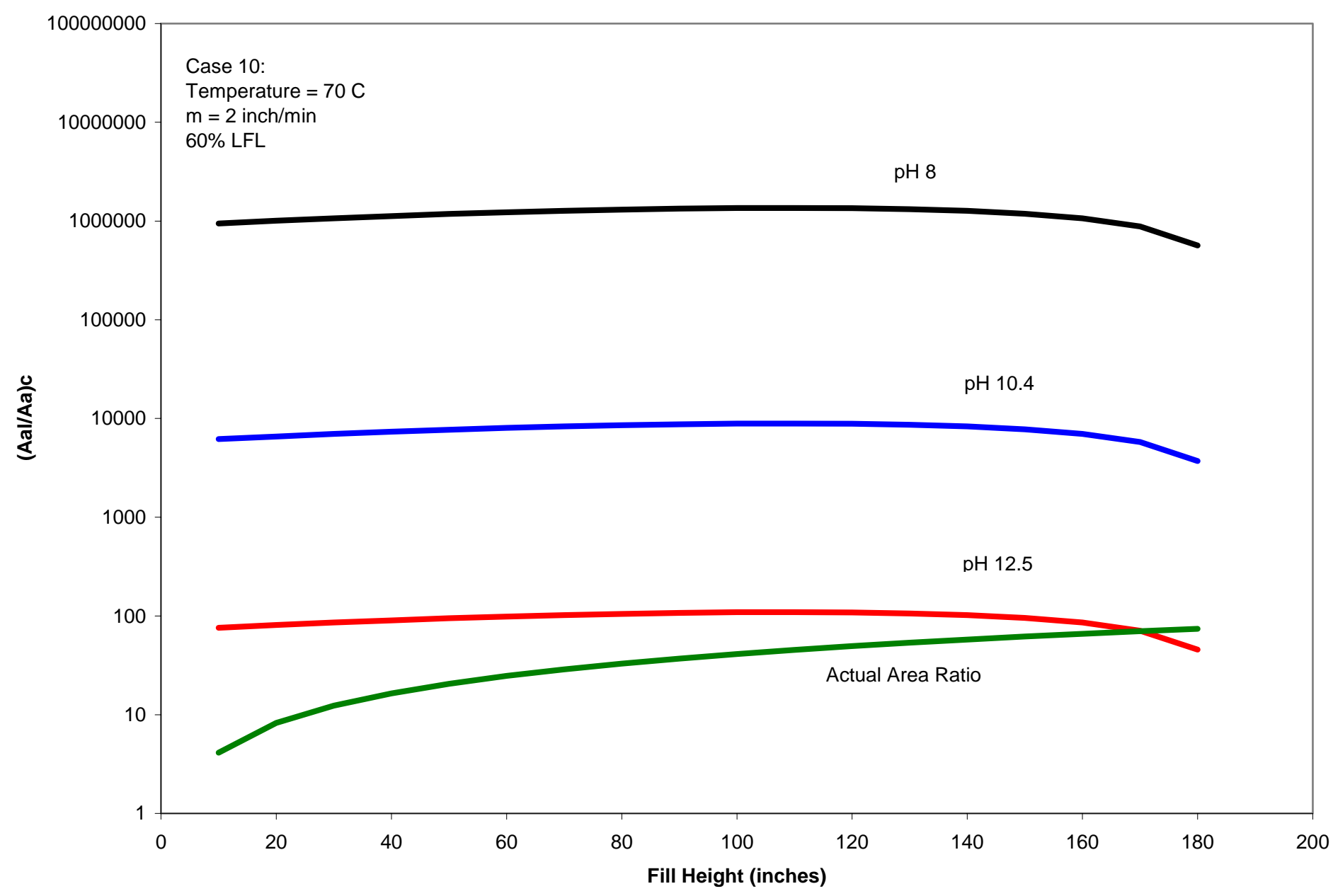

Figure 10. Critical areal density ratio for flammable condition in R\& P Reactor Vessels for Case 10. 


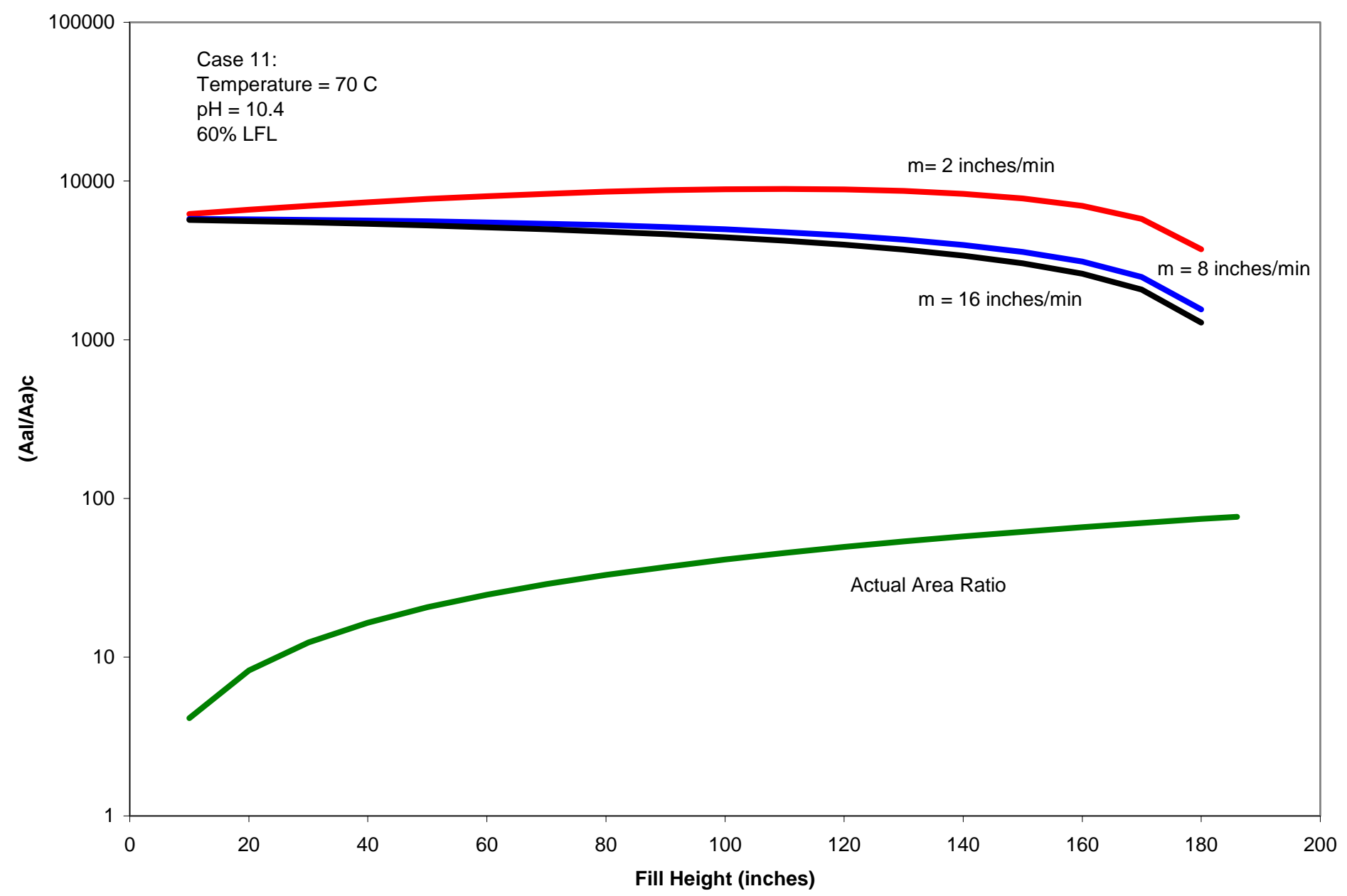

Figure 11. Critical areal density ratio for flammable condition in R\& $P$ Reactor Vessels for Case 11. 


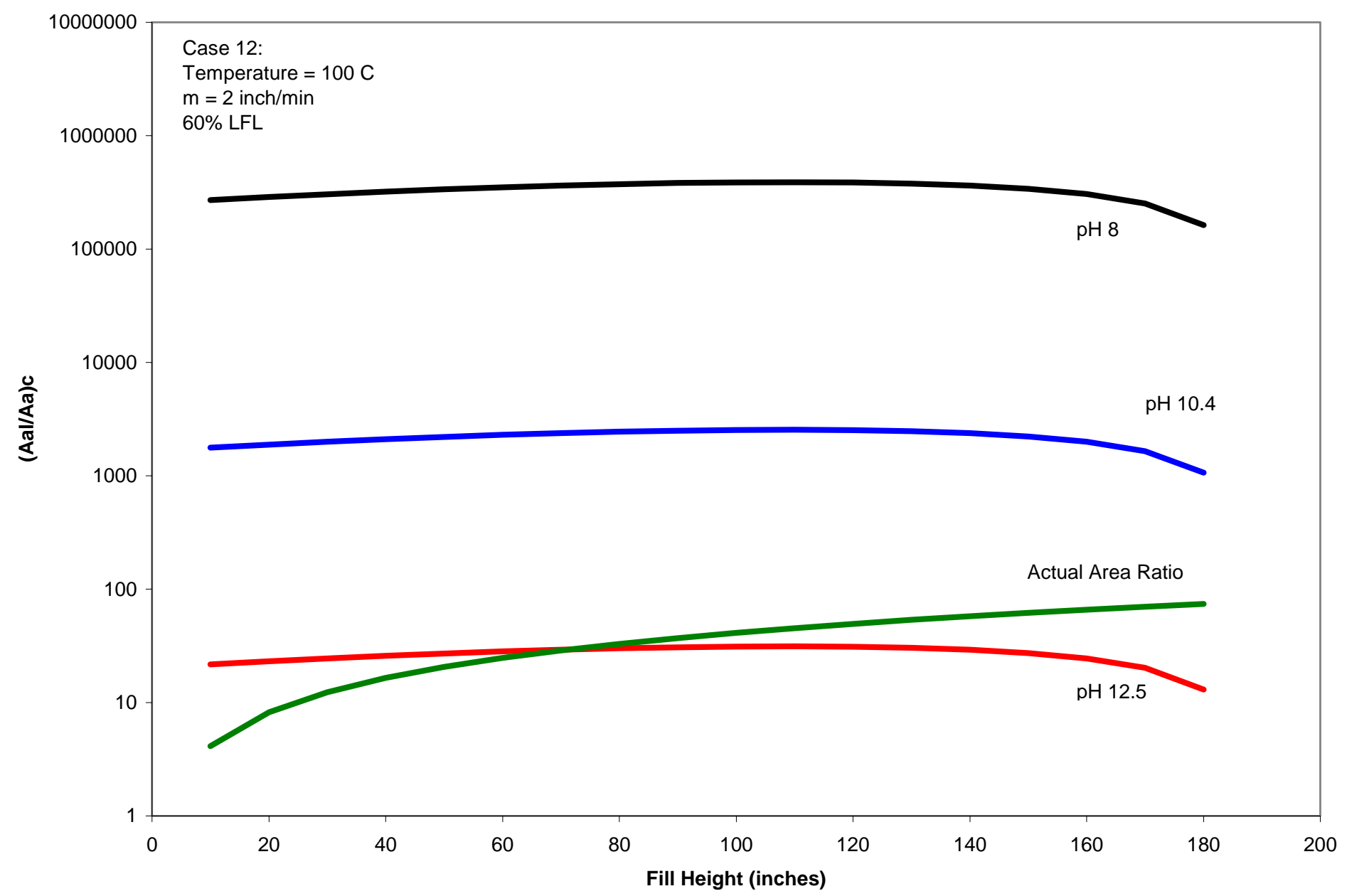

Figure 12. Critical areal density ratio for flammable condition in $R \& P$ Reactor Vessels for Case 12. 


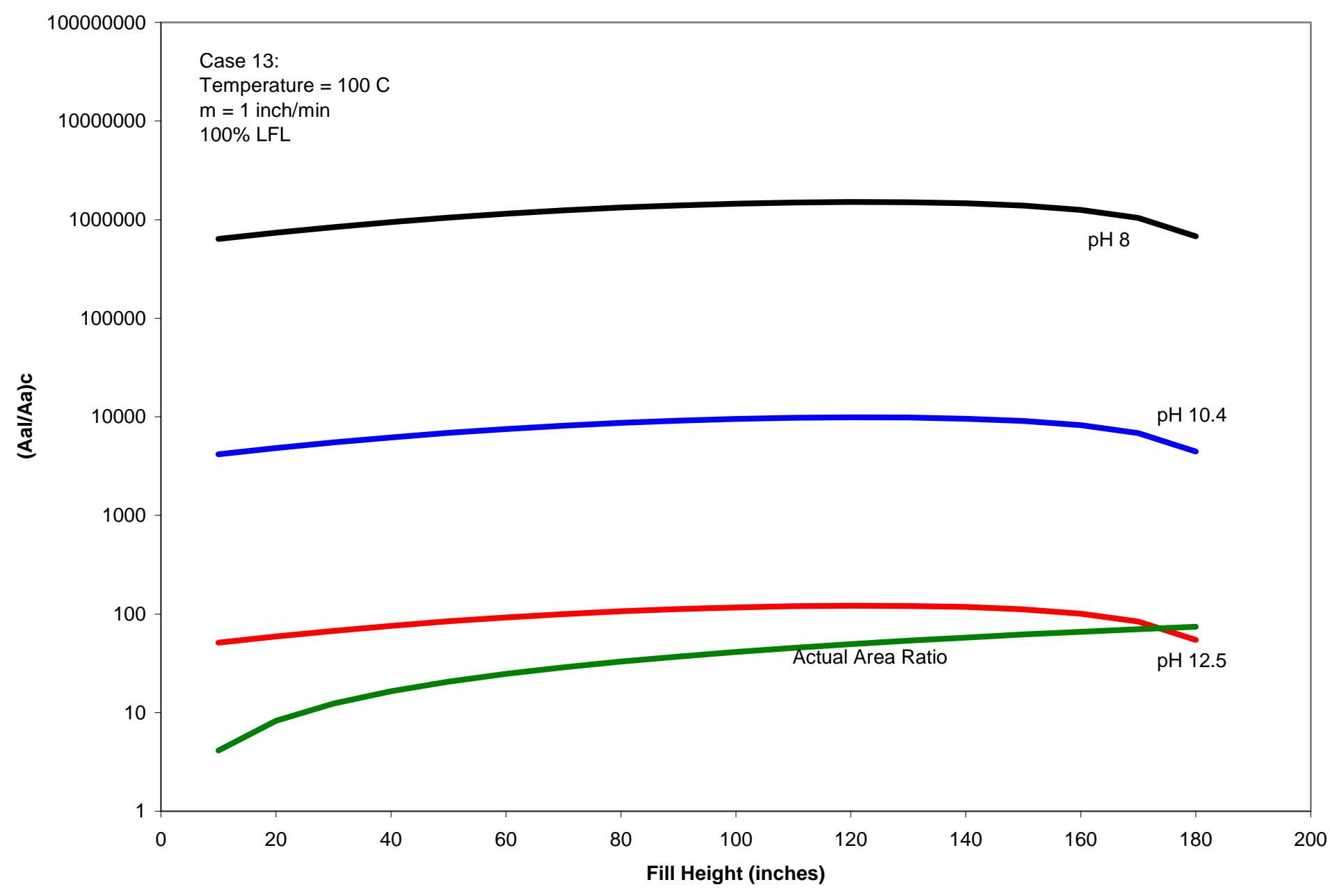

Figure 13. Critical areal density ratio for flammable condition in R\& P Reactor Vessels for Case 13. 


\section{Conclusions and Recommendations}

The evaluation concluded that either ceramicrete or the silica fume grout may be used to safely grout the R- and P- reactor vessels. The risk of accumulation of a flammable mixture of hydrogen between the grout-air interface and the top of the reactor is very low. Although these calculations are conservative, there are some measures that may be taken to further minimize the potential for hydrogen evolution.

1. Minimize the temperature of the grout as much as practical. Lower temperatures will mean lower hydrogen generation rates. Grout temperatures less than $100{ }^{\circ} \mathrm{C}$ should however, still provide an adequate safety margin for the $\mathrm{pH} 8$ and $\mathrm{pH} 10.4$ grout formulations.

2. Minimize the fill rate as much as practical. Lowering the fill rate takes advantage of passivation of the aluminum components and hence lower hydrogen generation rates. Fill rates that are less than 2 inches/min will reduce the chance of significant hydrogen build-up.

3. Ventilate the building as much as practical (e.g., leave doors open) to further disperse hydrogen. The volumetric hydrogen generation rates however, are low for the $\mathrm{pH} 8$ and $\mathrm{pH} 10.4$ grout, i.e., less than $0.32 \mathrm{ft}^{3} / \mathrm{min}$.

Portland cement grout, on the other hand, for the same range of process parameters does not provide a significant margin of safety against the accumulation of flammable gas in the reactor vessel during grouting operations. It is recommended that this grout not be utilized for this task. If further walk-down inspections of the reactor vessels suggest an increase in the actual areal density of aluminum, the calculations should be re-visited.

\section{References}

1. B. J. Wiersma, "Reactive Metal (Al) Interactions During Grouting Operations of the R- and P-Reactor Vessels," SRNL-RP-2009-01198," Rev. 0, September 2009.

2. B. J. Wiersma, "Assessment of the Potential for Hydrogen Generation During Grouting Operations in R-Reactor Disassembly Basin”, SRNL-STI-20090-00278, April, 2009.

3. S. M. Short and B. M. Parker, "Potential for Generation of Flammable Mixtures of Hydrogen from Aluminum-Grout Interaction During Basin Grouting", PNNL15156, April 2005.

4. M. Epstein and J. P. Burelbach, "Transient Vertical Mixing by Natural Convection in a Wide Layer", Int. J. Heat Mass Transfer, Vol. 43, pp. 321-325.

5. T. Matsuo, T. Nishi, and M. Matsuda, " $\mathrm{LiNO}_{3}$ Addition to Prevent Hydrogen Gas Generation from Cement-Solidified Aluminum Wastes”, J. Nuclear Science Technology, Vol. 32, No. 9, pp. 912-920, 1995.

6. T. Matsuo, et al., "LiNO3 Effect on Corrosion Prevention of Aluminum with Complex Shapes", J. Nuclear Science and Technology, Vol. 34, No. 8, pp. 823$828,1997$. 
7. T. Matsuo, et al., "Influence of Increased Temperature from Cement Hydration on Aluminum Corrosion Prevention when LiNO3 is Added to the Cement", Nuclear Technology, Vol. 125, pp. 332-336, March 1999.

8. B. C. Landeene, "CSTF Flammability Control Program”, WSRC-TR-2003-00087, Rev. 13, January 13, 2008.

9. H. Guerrero, "Thermo-Physical Characterization of Reactor Vessel Fill Materials for P and R Reactor In-Situ Decommissioning," SRNL-RP-2009-01185, September 2009.

10. N. Vrettos, "P\&R Reactor Void Volume and Surface Area Derivation", SRNLL1300-2009-00060, October 15, 2009.

11. Personal Communication from W. Epling to G. Rose, "Final As-Left Status of P Reactor Tank", October 9, 2006. 
SR $25-10(\operatorname{Rer} 6-18-92)$

ENGINEERING COMPUTATION SHEET

Title of Project R P Reactor Vessel Reactive Metal

Subject Derivation of $\mathrm{H}_{2}$ Generation Rate

Computer B.J. Wiersma
Project No.

Works

Date $9 / 30 / 09$

SIS

Sheet No. 1

Problem: Determine the hydrogen generation rate due to aluminum corrosion in the $R$ \& $P$ reactor vessels.

$Q=$ Hydrogen generation $\mathrm{cm}^{3} / \mathrm{min}-\mathrm{sm}^{2}$

$$
Q=g(h, T, p H)
$$

$h=$ height of grout in vessel Note: Height is a function of times

$T=$ temperature of grout

$p H=$ grout $p H$

$g(h)$ derivation

Inputs:

1) Due to passivation reactions [refl] the initial $\mathrm{H}_{2}$ generation rate decreases by 50D0 every 3 hours.

Half -life

Equation

$$
\begin{aligned}
& \frac{d^{\prime} g}{d t}=A g(t) \quad A=\text { constant } \\
& \frac{d g}{g}=A d t \quad \rightarrow \quad \ln g=A t+B \rightarrow Q=B e^{A t} \\
& \text { (a) } t=0 \quad g=Q_{0} \quad Q_{0}=\underset{\substack{\text { Inter } \\
\text { vatial }}}{H_{2} \text { generation }} \\
& g \circ=B \rightarrow g=Q_{0} e^{A t} \\
& \frac{g}{g 0}=0.5=e^{3 A} \rightarrow A=\frac{\ln 0.5}{3}=-2.31 \frac{1}{\mathrm{hr}} \\
& \text { g. }=Q_{0} e^{-2 \cdot 31 t}
\end{aligned}
$$

Reference:

[1] S.M. Short and B.M. Parker, "Potential for Generation of Flammable Mixtures of Hydrogen from Aluminum. Grout Interaction in the k-Basin Grouting", PNNL-15156, April 2005.

Page A-2 
SR $25-10$ (Rev 6-18-92)

ENGINEERING COMPUTATION SHEET

Title of Project R\&P Reactor Vessel Reactive Metal

Project No.

Subject Derivation of $\mathrm{H}_{2}$ Generation Rate

Works

Computer

B.J. Wiersma

Date 9/30/09

Sheet No. 2

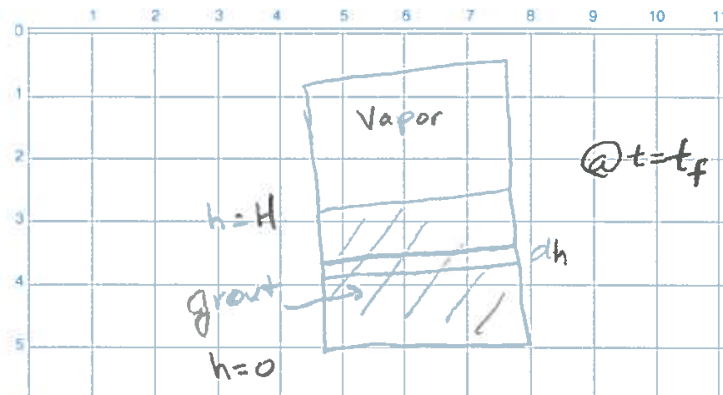

2) Fill level increases as a linear function of time

$$
h=m t \quad m=\text { fill rate in inches/min }
$$

Vessel

Perform a mass balance at $t=t_{f}$ to determine the hydrogen generation rate from each volume slice $A_{c} d h . A_{c}$ is the open cross-sectional area of the vessel.

$$
\begin{aligned}
g A_{0} H & =\int_{0}^{H} Q_{0} e^{-23 t} A_{c} d h \quad t=\frac{h}{m} \\
g H & =Q_{0}^{H} e^{-2.31 \frac{h}{m}} d h \\
g & =-\left.\frac{Q_{0}}{H} \frac{m}{2.31 * \frac{1 h r}{60 * i n}} e^{-2.31 \times \frac{t}{60} \frac{h}{m}}\right|_{0} ^{H} \\
& =-\frac{Q_{0}}{H} \frac{m}{0.0385}\left[e^{-0.0385 \frac{H}{m}}-1\right] \\
g & =\frac{Q_{0} m}{0.0385 H}\left[1-e^{-0.0385 \frac{11 / m}{m}}\right]
\end{aligned}
$$

Page A-3 
OSR 25-10 (Rev 6-18-92)

Title of Project R $\pm P$ Reactor Vessel Reactive Metal

Project No.

subject Derivation of $\mathrm{H}_{2}$ Generation Rate

Works

Computer B.J. Wiersma Date $9 / 30 / 04$

Sheet No. 3

$$
\begin{aligned}
& Q_{0}(p H, T)=S(T) U(p H) \\
& U(p H)
\end{aligned}
$$

Literature Values for corrosion rates of aluminum as a function of $p H$

Chatalov [ref, i] Data@ $30^{\circ} \mathrm{C}$

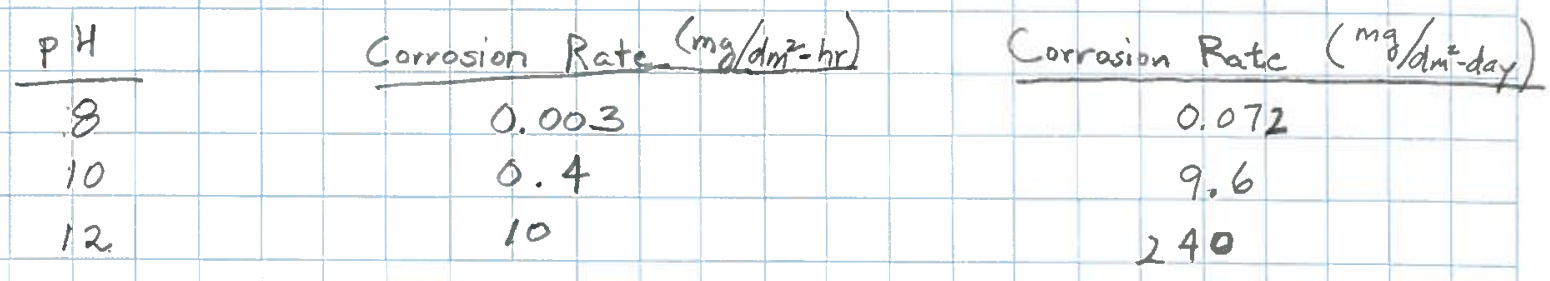

$M=$ Gee and Brown [ref.3] Data @30 $30^{\circ} \mathrm{C}$

\begin{tabular}{c|cc}
$\frac{p H}{10}$ & Corrosion Rate $\left(\mathrm{mg} / \mathrm{cm}^{2}-\right.$ day $)$ & $\left.\frac{\text { Corrosion Rate }\left(\mathrm{mg} / \mathrm{dm}^{2}-\text { day }\right.}{2}\right)$ \\
\cline { 2 - 3 } 11 & 0.02 & 30 \\
12 & 0.3 & 400 \\
13 & 4 & 3000
\end{tabular}

Corrosion of Aluminum: Net reaction in caustic

$$
2 \mathrm{Al}+3 \mathrm{H}_{2} \mathrm{O} \rightleftharpoons \mathrm{Al}_{2} \mathrm{O}_{3}(\mathrm{~s})+3 \mathrm{H}_{2} \uparrow
$$

$\therefore \quad 1.5$ moles of $H_{2}$ evolve for every mole of $\mathrm{Al}$ corroded.

References

[2] Chatalor in Atlas of Electrochemical Equilibrial in Aqueous Solutions, M. Pourbaix, NACE, Houston, TX, 1974.

[3] A.B. Mckee and R.H. Brown," Resistance of Aluminum to Corrosion in Solutions Containing Various Anions and Cations", Corrosion, Vol.3, Dec. 1947, p.595.

Pane $A-4$ 
OSR 25-10 (Rev 6-18-92)

ENGINEERING COMPUTATION SHEET

Title of Project R\&P Reactor Vessel Reactive Metal

Project No.

subject Derivation of $\mathrm{H}_{2}$ Generation Rate

Works

computer B.J. Wiersma

Date $9 / 30 / 09$

Sheet No. 4

Equation for converting corrosion rate to $\mathrm{H}_{2}$ generation rate

Idea Gas Law $\quad V=\frac{n}{p}$

$$
\begin{aligned}
& R=\text { Gas Constant }=0.0821 \frac{\mathrm{l}-\mathrm{atm}}{\text { mote k }} \\
& T=\text { Temperature }=303 \mathrm{~K} \\
& P=\text { Pressure }=1 \mathrm{~atm} \\
& n=\text { moles }=\frac{\text { mass }}{M w} \\
& M W=\text { Molecular Wt. of } \mathrm{Al}=27 \mathrm{~g} / \mathrm{mole}=27,000 \frac{\mathrm{mg}}{\mathrm{mole}}
\end{aligned}
$$

$$
\begin{aligned}
& \frac{P H}{8} \\
& \frac{\text { Corrosion Rate (moles } \left./ 2 m^{2}-d a y\right) \text { ) }}{2.67 \times 10^{-6}} \\
& \text { Corrosion Rate (Moles } A I) \\
& 3.55 \times 10^{-4} \\
& 1.85 \times 10^{-11} \\
& 10 \\
& 7.41 \times 10^{-5} \\
& 2.47 \times 10^{-9} \\
& 10 \\
& 1.11 \times 10^{-3} \\
& 5.5 \times 10^{-10} \\
& 11 \\
& 8.88 \times 10^{-3} \\
& \text { 7. } 71 \times 10^{-9} \\
& 12 \\
& .48 \times 10^{-2} \\
& 6.17 \times 10^{-8} \\
& 12 \\
& 1.11 \times 10^{-1} \\
& 1.03 \times 10^{-7} \\
& 13 \\
& 7.71 \times 10^{-7} \\
& U(R H)=\text { Corr. Rate } \times\left(\frac{1.5 \text { moles } H_{2}}{\text { mole } t 1}\right) R T
\end{aligned}
$$

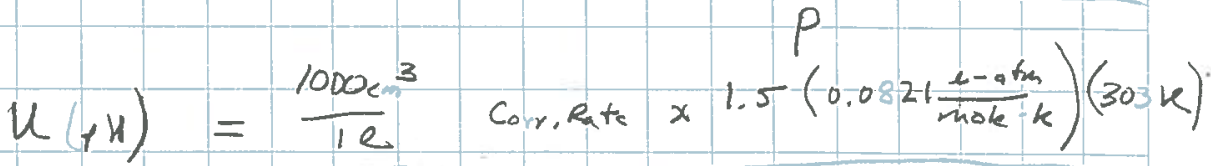

$$
\begin{aligned}
& 1-a+m \\
& =3.73 \times 10^{4} \text { * Corr. rate }
\end{aligned}
$$

Page A-S 
OSR 25-10 (Rev 6.18-92)

ENGINEERING COMPUTATION SHEET

Title of Project R\&P Reactor Vessel Reactive Metal Project No.

subject Derivation of Hz Generation Rate

Works

Computer B.J. Wiersma Date 9/30/09

Sheet No. 5

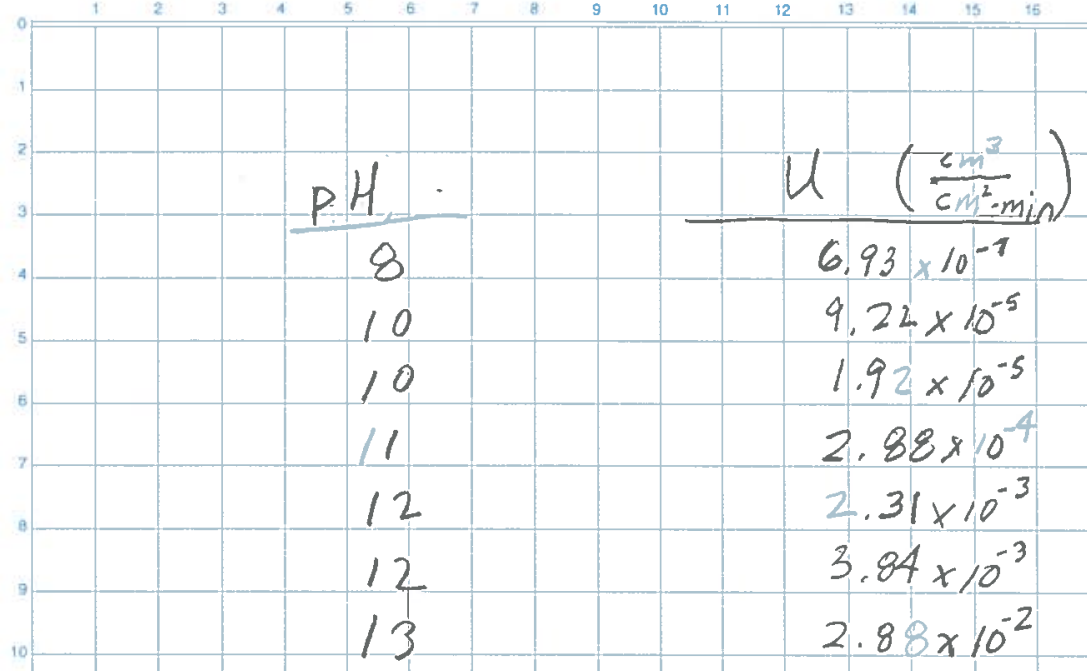

PNNL report [ref []: U: $0.3 \mathrm{~cm}^{3} / \mathrm{min}$ on a $48.3 \mathrm{~cm}^{2}$ sample @.p. 412.5

$$
u=6.21 \times 10^{-3} \mathrm{~cm}^{3} / \mathrm{cm}^{2}-\min
$$

(a) $27^{\circ} \mathrm{C}$

Note: Hz generation rate in grout agrees w/literature

See plot of pH vs. $U$ on sheet No. 6

$$
U(p H)=3 \times 10^{-14} e^{2.0952 * p^{4}} \mathrm{~cm}^{3}
$$

@ $T=30^{\circ} \mathrm{C}$

Curve was fitted using EXCEL regression fit

$S(T)$ derivation

- Hydrogen generation rate can be described by the Arrhenius en.

- $\quad \mathrm{H}_{2}$ generation in $\mathrm{C}(\mathrm{OH})_{2}$ solutions increased by a factor of 5 as the solution temperature increased from

$$
\begin{aligned}
& 23^{\circ} \mathrm{C}+52^{\circ} \mathrm{C} \text { [ret. 1] } \\
& Q_{H_{2}}^{\prime}(23 C)=Q_{0}^{\prime} \exp \left(\frac{-T_{T^{+}}}{29 B}\right) \\
& Q_{H_{2}}^{\prime}(s 2 c)=Q_{0}^{0} \exp \left(\frac{-T_{a c t}}{3-2 s}\right) \\
& Q_{H_{2}}^{\prime}(52 C)=5 Q_{0}^{\prime}(23 E)
\end{aligned}
$$

(Go to sheet 7)

Page A-6 
Project: R\&P Reactor Vessel Reactive Metal

Subject: Derivation of $\mathrm{H}_{2}$ generation Rate

Computer: $B_{\text {. J. Wiersma }}$

Date : $9 / 30 / 09$

Sheet : $6 \quad$ U (cc/min/sq.cm)
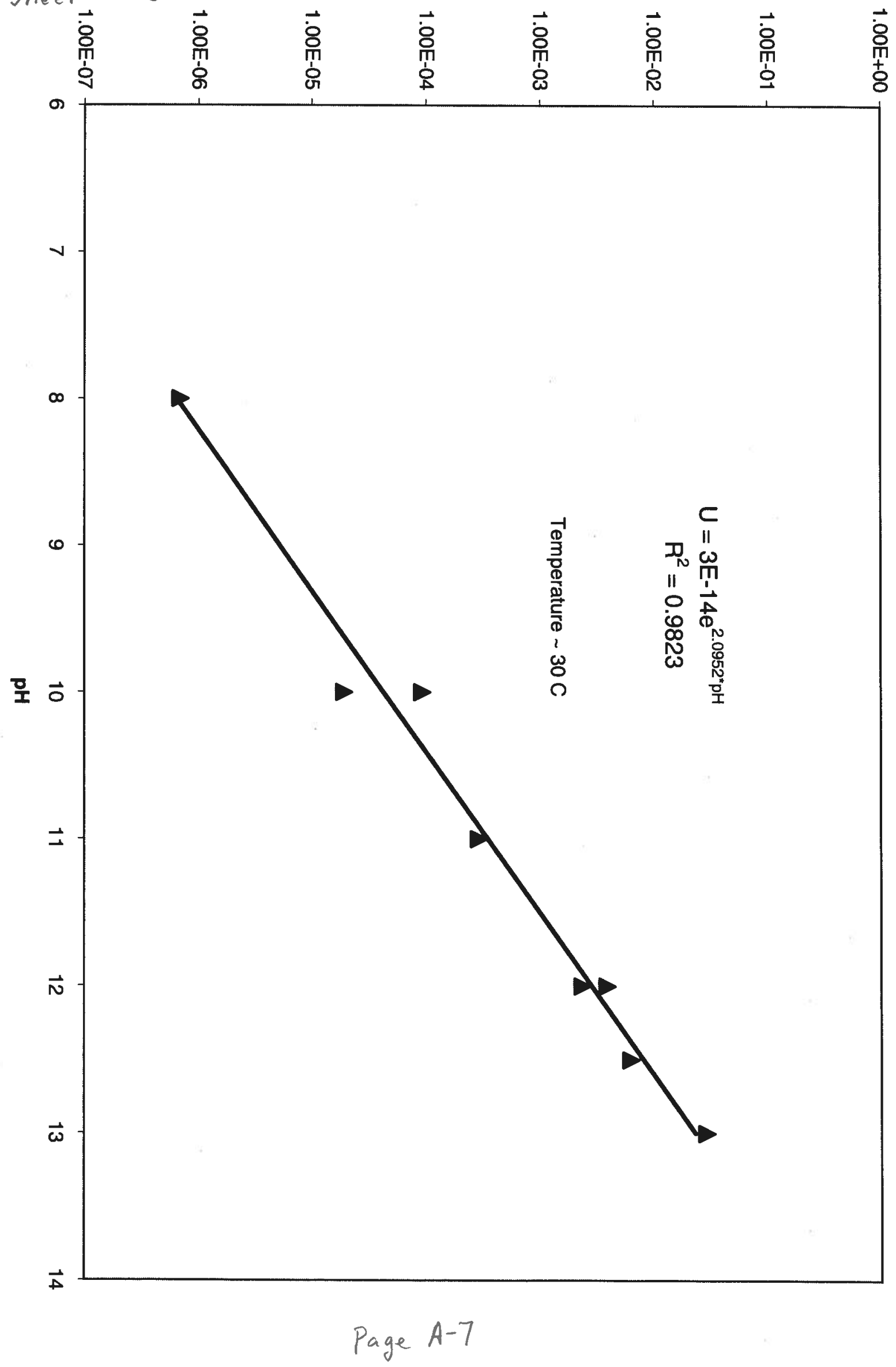
OSR 25. 10 (Res 6-18-93)

ENGINEERING COMPUTATION SHEET

Title of Project $R \notin P$ Reactor Vessel Reactive Metal

Project No.

subject Derivation of $\mathrm{H}_{2}$ generation Rete

Works

Computer B.J. Wiersme

Date

$10 / 3109$

Sheet No. 7

$$
\begin{aligned}
& 5 Q_{0}^{\prime} \exp \left(\frac{T_{\text {Tat }}}{246}\right)=Q_{0}^{\prime} \exp \left(\frac{-T_{\text {act }}}{326}\right) \\
& 5=\exp \left(\frac{T_{\text {at }}}{216}-\frac{T_{\text {ad }}}{325}\right) \\
& n 5=\operatorname{Tact}\left(\frac{1}{286}-\frac{1}{325}\right) \\
& \text { Tact }=5339 \mathrm{~K} \\
& S(T)=Q_{j}^{\prime} \exp \left(-\frac{5339}{T}\right) \\
& Q_{0}(p H I)=3 \times 10^{-4} e^{2.0952 p^{4}} \exp \left(-5339\left(\frac{T}{T}-\frac{1}{803}\right)\right) \frac{\mathrm{cm}^{3}}{\mathrm{~cm}^{2}-\min } \\
& \left.Q=\frac{Q_{0} m}{0.0385}\left[1-\exp \left(\frac{-0.0385 \mathrm{H}}{\mathrm{m}}\right)\right]\right] \frac{\mathrm{cm}^{3}}{\mathrm{~cm}^{2} \min }
\end{aligned}
$$

Vertical Turbulent Diffusion [ret. 1]

$U_{0}=$ Superficial Velocity @ grout Level H

$$
u_{0}=\beta^{2}\left[g H_{0}\left(1-\frac{M H_{A}}{M_{A}}\right) x_{L E_{L}}^{3}\right]^{1 / 2}
$$

$X_{\text {HL }}=0.024$ volume $\eta_{0} H_{2}$ Q $60 \%$ of the lower flammability limit $H_{0}=$ distance from grout level to top of reactor

$H_{0}=(186-H)$ $186^{\prime \prime}=$ height of Reactor $H=$ level of grout $g=9.8 \mathrm{~m} / \mathrm{s}^{2}$

$\beta=$ proportionality constant $=0.164$

$M_{H_{2}}=$ Molecular wt of $H_{2}=2 \mathrm{~g} / \mathrm{mole}$

$M_{\text {H }}=$ Molecular wt of $A r=29 \mathrm{~g} / \mathrm{mole}$$$
u_{0}=(0.164)^{2}\left[9.8 \frac{\mathrm{m}}{\mathrm{s}^{2}}\left(\frac{1.00 \mathrm{~m}}{\mathrm{im}}\right)(186-H) *(2.539 \mathrm{~g})\left[1-\frac{2}{29}\right]\left[0.044^{3} \times \frac{3600 \mathrm{~s}^{2}}{\mathrm{~min}^{2}}\right]^{1 / 2}\right.
$$$$
u_{0}=(0.164)^{2}[115+(186-4)]^{1 / 2} \frac{\mathrm{cm}^{3}}{\mathrm{~cm}^{2}-\min }
$$

Page A- 8 
OSR 25-10 (Rev 6-18-92)

ENGINEERING COMPUTATION SHEET

Title of Project R\&P Reactor Vessel Reactive Metal Derivation of Critical Areal Density Ratio Computer B.J. Wiersma
Project No.

Works

Date $\quad 10 / 7 / 09$

SiRS

Sheet No. 8

The incipient flammability condition occurs when the gas generation rate due to corrosion equals the turbulent diffusion rate of hydrogen through air. The boundary condition is that the $\mathrm{H}_{2}$ concentration at the interface between the grout and the vapor space is at $60 \% 0 \mathrm{fL}$. The 60\% LFL criterion provides a safety margin against the possibility of developing a flammable mixture. This safety margin is used for the flammability calculations for the radioactive waste tanks at Savannah River Site [ref. 4]. The equation is:

$$
\begin{aligned}
& Q A_{A .1}=u_{0} A_{a} \\
& \frac{A_{A 1}}{A_{a}}=\frac{u_{0}}{Q}
\end{aligned}
$$

where $A_{A 1}$ is the aluminum surface area in contact $w /$ grout and $A_{a}$ is the void cross-sectional area of the reactor vessel

A plot of $\frac{A_{A 1}}{A_{a}}$ VS. H (the grout fill level) is prepared. The ratio is a function of temperature, $p H$, and fill rate. An example plot is shown on sheet 9. Also included on the plot is the actual ratio of $A_{A_{1}} / A_{a}$ as a function of $H$ (see sheet 10 for derivation). If the calculated values for $A_{A 1} / A_{a}$ are less than the actual the margin on the LFL condition has been reduced. Safe operating conditions exist when the calculated values are greater than the actual values.

Calculations were performed on an EXCEL spreadsheet.

Reference 4: B.C. Landeene, "CSTF Flammability Control Program", WSRC-TR-2003-00087, rev. 13, January 31,2008.

Page A-G 
Project: R\&P Reactor Vessel Reactive Metal

Subject: Derivation of Critical Areal Density Ratio

Computer: B.J. Wiersma

Date : 10/7log

(Aal/Aa)c

Sheet No. : 9
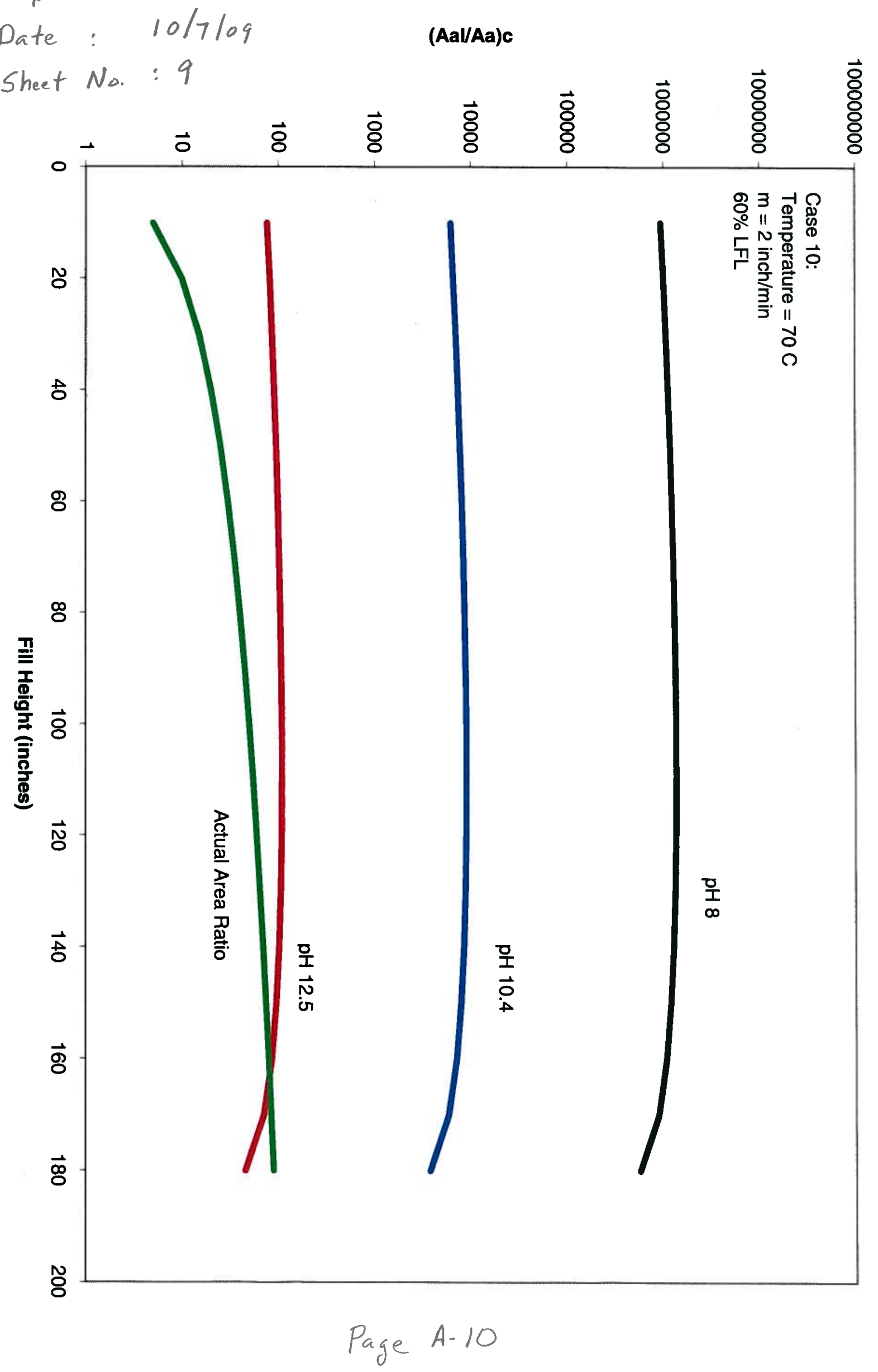
$\operatorname{OSR} 25.10(\operatorname{Res} 6.18 .93)$

ENGINEERING COMPUTATION SHEET

Title of Project $R \& P$ Reactor Vessel Reactive Metal Project No.

Subject Calculation of Actual Areal Density Ratio Works

Computer B.J. Wiersma Date $10 / 22 / 09$

Sheet No. 10

Calculate surface area of aluminum exposed to grout. Use equation 7 .

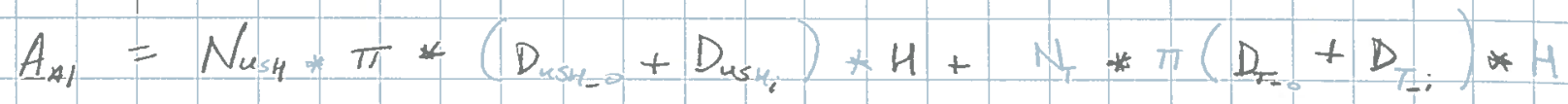

(a) $H=10$ inches

$$
\begin{aligned}
A_{A 1} & =432 * \pi *\left(4.25^{\prime \prime}+4.0^{\prime \prime}\right) * 10^{\prime \prime}+66 * \pi\left(.1 .5^{\prime \prime}+1.0^{\prime \prime}\right) * 10^{\prime \prime} \\
& =112,150 \mathrm{in}^{2}
\end{aligned}
$$

Cross- Sectional Area of Reactor vessel. Use Equation 8.

$$
\begin{aligned}
& A_{a}=\pi+D_{t}^{2} / 4-N_{u s 4} * \pi *\left(D_{u s H_{0}}^{2}-D_{u-s H_{-i}}^{2}\right) / 4 \\
& -N_{T} * \pi *\left(D_{T-0}^{2}-D_{T-i}^{2}\right)\left(4-N_{s s} * \pi * D_{S}^{2} / 4\right. \\
& A_{c}=\pi / 4 *\left(194.75^{\prime}\right)^{2}-432 * \frac{\pi}{4} *\left(4.25^{2}-4^{12}\right)-66 * \frac{\pi}{4} *\left(1.5^{2}-1.0\right)^{2} \\
& -67 * \frac{\pi}{4} * 3.5^{12} \\
& =28,-379 \mathrm{in}^{2}
\end{aligned}
$$

(a) $H=10$

$$
\frac{A_{A 1}}{A_{a}}=\frac{117,150 \mathrm{in}^{2}}{28,379 \mathrm{in}^{2}}=4.13
$$

Agrees w/ EXCEL spreadsheet 
OCR $25-10(\operatorname{Rev} 6-18-92)$

ENGINEERING COMPUTATION SHEET

Title of Project $R \& P$ Reactor Vessel Reactive Metal Project No.

Subject Derivation of Maximum Flow Rate of $\mathrm{H}_{2}$

Works

Computer B.J. Wiersma

Date $10 / 16 / 09$

Sheet No.

Problem: Determine the maximum volumetric flow rate of $H_{2}$.

Approach: Use the equation for the generation of H. from corrosion (EIn.Z) and the equation for the surface area of aluminum (Es, Z) to determine the volumetric flow rate of aluminum!

$$
Q_{\text {ToT }}=Q+A_{A 1}
$$

Determine maximum by taking derivative of Qto with respect to $H$. Set this equal to zero and solve for $H$. The maximum could also be at the boundary condition. Check these as well for Hoax. Determine $Q_{\text {Tor }}$ at $H_{\max }$ and at the boundary condition. It is assumed that $T ; P H$, and fill rate are constant. Calculate the maximum QTo for each case study.

$$
\begin{aligned}
& Q_{\text {ToT }}=Q \times A_{A_{1}}
\end{aligned}
$$

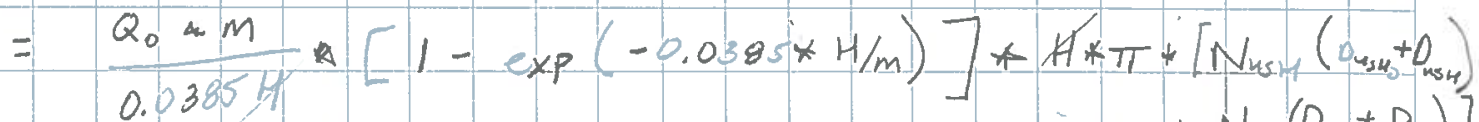

$$
\begin{aligned}
& \left.+N_{T}\left(R_{T}+R_{i}\right)\right]
\end{aligned}
$$

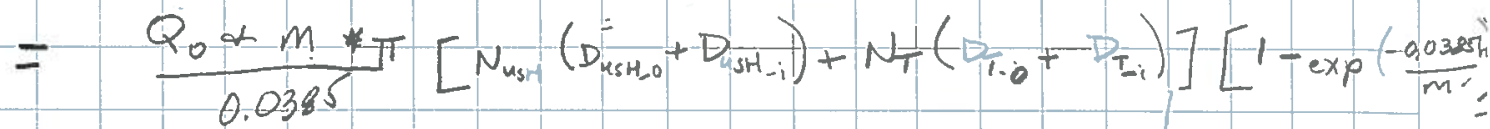

$$
\begin{aligned}
& \frac{d \theta_{\text {or }}}{d H}=0=B\left[0-\left(-\frac{0.0385}{m}\right) \exp \frac{(-0.0395+H}{m}\right]
\end{aligned}
$$

Maximum $Q_{\text {Tor }}$ is at upper boundary. Assume height of reactor 186 inches $Q_{\text {ToT }}$ is calculated in spreadsheet 
OR $25-10(\operatorname{Rev} 6-18-92)$

ENGINEERING COMPUTATION SHEET

Title of Project R\&P Reactor Vessel Reactive Metal

Project No.

subject Derivation of Calculation of Maximum Flow Rate off Works computer B.J. Wiersma

Date $\quad 10 / 16 / 09$

Sheet No. 12

(186 inches

$$
\begin{aligned}
& T=100^{\circ} \mathrm{C} \quad m=2 \text { inches/min } \mathrm{H} 12.5 \\
& N_{\text {ut }}=432 \quad N_{T}=66 \quad D_{\text {ut } N_{-0}}=4.25^{\prime \prime} D_{\text {ugH }}=4.0^{\prime \prime} \\
& D_{T_{0}}=1.5^{\prime \prime} \quad D_{T \cdot j}=1.0^{\prime \prime} \\
& Q_{0}=3 \times 10^{-14} \exp (2.0952 * p H) * \exp \left[-5339 *\left(1 / 373-\frac{1}{303}\right)\right]
\end{aligned}
$$$$
=0.194 \mathrm{~cm}^{3} / \mathrm{cm}^{2} / \mathrm{min}
$$

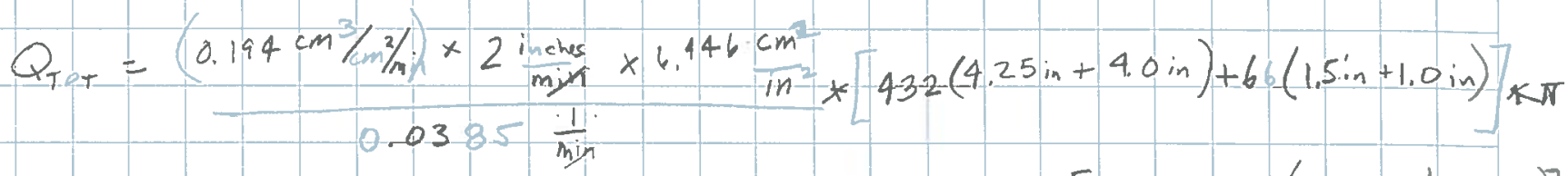

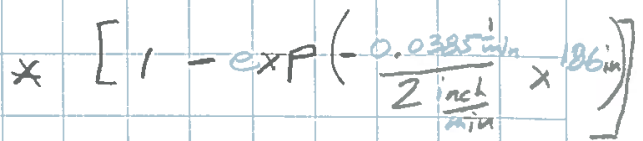

$$
\begin{aligned}
& =\quad 739,827 \frac{\mathrm{cm}^{3}}{\mathrm{~min}}=0.740 \frac{\mathrm{m}^{3}}{\mathrm{~min}} \mathrm{H}_{2} \\
& =26.1 \mathrm{f} \mathrm{ft} 3 / \mathrm{min} \mathrm{H}_{2}
\end{aligned}
$$

Conservative because it neglects diffusion of $\mathrm{H}_{2}$ through the grout. 